\title{
Future changes in the stratosphere-to-troposphere ozone mass flux and the contribution from climate change and ozone recovery
}

\author{
Stefanie Meul $^{1}$, Ulrike Langematz ${ }^{1}$, Philipp Kröger ${ }^{1}$, Sophie Oberländer-Hayn ${ }^{1}$, and Patrick Jöckel ${ }^{2}$ \\ ${ }^{1}$ Institut für Meteorologie, Freie Universität Berlin, Berlin, Germany \\ ${ }^{2}$ Deutsches Zentrum für Luft- und Raumfahrt (DLR) e.V., Institut für Physik der Atmosphäre, \\ Oberpfaffenhofen, Germany
}

Correspondence: Ulrike Langematz (ulrike.langematz@met.fu-berlin.de)

Received: 22 January 2018 - Discussion started: 31 January 2018

Revised: 30 April 2018 - Accepted: 4 May 2018 - Published: 1 June 2018

\begin{abstract}
Using a state-of-the-art chemistry-climate model we investigate the future change in stratosphere-troposphere exchange (STE) of ozone, the drivers of this change, as well as the future distribution of stratospheric ozone in the troposphere. Supplementary to previous work, our focus is on changes on the monthly scale. The global mean annual influx of stratospheric ozone into the troposphere is projected to increase by $53 \%$ between the years 2000 and 2100 under the RCP8.5 greenhouse gas scenario. The change in ozone mass flux (OMF) into the troposphere is positive throughout the year with maximal increase in the summer months of the respective hemispheres. In the Northern Hemisphere (NH) this summer maximum STE increase is a result of increasing greenhouse gas (GHG) concentrations, whilst in the Southern Hemisphere(SH) it is due to equal contributions from decreasing levels of ozone depleting substances (ODS) and increasing GHG concentrations. In the SH the GHG effect is dominating in the winter months. A large ODS-related ozone increase in the SH stratosphere leads to a change in the seasonal breathing term which results in a future decrease of the OMF into the troposphere in the $\mathrm{SH}$ in September and October. The resulting distributions of stratospheric ozone in the troposphere differ for the GHG and ODS changes due to the following: (a) ozone input occurs at different regions for GHG- (midlatitudes) and ODS-changes (high latitudes); and (b) stratospheric ozone is more efficiently mixed towards lower tropospheric levels in the case of ODS changes, whereas tropospheric ozone loss rates grow when GHG concentrations rise. The comparison between the moderate RCP6.0 and the extreme RCP8.5 emission scenarios reveals that the annual global OMF trend is smaller in the
\end{abstract}

moderate scenario, but the resulting change in the contribution of ozone with stratospheric origin $(\mathrm{O} 3 \mathrm{~s})$ to ozone in the troposphere is of comparable magnitude in both scenarios. This is due to the larger tropospheric ozone precursor emissions and hence ozone production in the RCP8.5 scenario.

\section{Introduction}

Ozone $\left(\mathrm{O}_{3}\right)$ in the troposphere has two sources: photochemical production involving ozone precursor species such as nitrogen oxides $\left(\mathrm{NO}_{x}\right)$, carbon monoxide $(\mathrm{CO})$, and hydrocarbons (e.g., methane $\left(\mathrm{CH}_{4}\right)$ ) and the transport of ozone from the stratosphere into the troposphere (i.e., stratospheretroposphere exchange, STE) (IPCC, 2001). Mass can be exchanged between the stratosphere and the troposphere along isentropic surfaces which intersect the tropopause in the lowermost stratosphere (LMS) (Holton et al., 1995), where the chemical lifetime of ozone is larger than the transport timescale. Tropopause folds in the vicinity of the polar and the subtropical jets and cutoff lows are important structures for the effective transport of stratospheric air masses into the troposphere because of their large displacement of the tropopause on isentropic surfaces (Stohl et al., 2003). Mass exchange is also possible by slow cross-isentropic transport, which is driven by diabatic cooling (Stohl et al., 2003) through the large-scale vertical motion of air in the stratospheric meridional residual circulation, the Brewer-Dobson circulation (BDC).

Earlier studies have shown that in a changing climate the mass transport from the stratosphere will increase due to a 
strengthened BDC (e.g., Butchart and Scaife, 2010; Butchart et al., 2010; Oberländer et al., 2013). Akritidis et al. (2016) found coinciding increases in the frequency of tropopause folds in summer over the eastern Mediterranean and in stratospheric ozone in the lower troposphere between 1979 and 2013. In addition to changes in the ozone transport from the stratosphere into the troposphere, ozone concentrations in the stratosphere are expected to change. Due to declining halogen levels in the stratosphere following the regulation of ozone depleting substances (ODS) by the Montreal Protocol and its amendments, stratospheric ozone is projected to recover during the 21 st century (e.g., WMO, 2014). In addition, radiative cooling of the stratosphere associated with the rising concentrations of well-mixed greenhouse gases (GHG) (i.e., carbon dioxide $\left(\mathrm{CO}_{2}\right)$, nitrous oxide $\left(\mathrm{N}_{2} \mathrm{O}\right)$, and $\mathrm{CH}_{4}$ ) will lead to reduced ozone loss rates and an ozone increase in the stratosphere (e.g., Jonsson et al., 2004). Besides the temperature effect of the GHGs (mainly $\mathrm{CO}_{2}$ ) on the ozone chemistry, the increasing abundances of $\mathrm{CH}_{4}$ and $\mathrm{N}_{2} \mathrm{O}$ also have an impact on the net production of stratospheric ozone: while higher $\mathrm{N}_{2} \mathrm{O}$ concentrations are associated with enhanced ozone loss in the stratosphere due to reactive nitrogen, a $\mathrm{CH}_{4}$ increase not only causes larger ozone loss in the lower and upper stratosphere but also leads to increased ozone production in the lower stratosphere where it acts as an ozone precursor (e.g., Revell et al., 2012). In addition, $\mathrm{CH}_{4}$ plays a role in polar ozone chemistry owing to the fact that changing $\mathrm{CH}_{4}$ concentrations also alter the partitioning between halogen reservoir gases and activated halogen species (e.g., Nevison et al., 1999). The combined effect of increasing GHG concentrations (including the interactions between the chemical cycles) on the net stratospheric ozone production is positive (e.g., Meul et al., 2014).

Both, the intensified stratospheric circulation, and the concurrent increase of stratospheric ozone are expected to lead to an increase in the ozone mass entering the troposphere (e.g., Stevenson et al., 2006; Shindell et al., 2006; Hegglin and Shepherd, 2009; Young et al., 2013; Banerjee et al., 2016). Previous studies using different models and approaches have indicated the dominant role of stratospheric circulation changes for the increased STE (e.g., Sudo et al., 2003; Zeng and Pyle, 2003; Collins et al., 2003). Also in observational data, the connection between stratospheric circulation changes and tropospheric ozone variations has been identified (Neu et al., 2014). However for the past, Ordóñez et al. (2007) showed that changes in the lowermost stratospheric ozone concentrations have a larger effect on the STE change than variations in cross-tropopause air mass transport. A reduced STE due to stratospheric ozone depletion in the past was found by Shindell et al. (2006) to offset more than half of the tropospheric ozone increase since preindustrial times. The influence of stratospheric ozone recovery on STE in the future was reported by Zeng et al. (2010) who showed that in the Southern Hemisphere (SH) during winter stratospheric ozone increase and climate change have a nearly equal contribution to the increase in surface ozone under the A1B scenario. More recently, the drivers of future STE changes have been analyzed by Banerjee et al. (2016) in model simulations. Neglecting the impact of methane and $\mathrm{N}_{2} \mathrm{O}$, they find that ODS and climate change under the RCP8.5 scenario contribute almost equally to the annual global STE increase between 2000 and 2100.

Rising GHG concentrations, however, do not only affect the stratospheric circulation and chemistry. In the troposphere, GHG-induced warming increases the water vapor content and thus tropospheric ozone destruction (e.g., Johnson et al., 1999). This results in a decrease of chemical ozone lifetimes (e.g., Zeng et al., 2010; Banerjee et al., 2016) which means that the distribution and the burden of stratospheric ozone entering the troposphere are also altered.

In addition to a changing amount of stratospheric ozone in the troposphere, changing future emissions of ozone precursor species will affect the local ozone production in the troposphere (e.g., Monks et al., 2009). Large differences exist in the temporal evolution of the emissions between the Representative Concentration Pathways (RCPs) for the radiative forcing of 6.0 and $8.5 \mathrm{~W} \mathrm{~m}^{-2}$ (Meinshausen et al., 2011), especially for $\mathrm{CH}_{4}$. This will result in larger ozone production under the RCP8.5 scenario at the end of the 21 st century compared to the RCP6.0 scenario. As a consequence, the importance of stratospheric ozone in the troposphere in the future will depend on the net tropospheric chemical ozone production.

Most studies addressing the question of future STE changes and their role in tropospheric ozone trends focus on the annual and global integrated fluxes. Hegglin and Shepherd (2009) also showed the annual cycle of the OMF derived from a box model approach introduced by Appenzeller et al. (1996). In their model simulation, the maximum ozone flux occurs in spring in the $\mathrm{SH}$ and $\mathrm{NH}$ for the 1960 to 1970 mean. In the future (2090-2100), the peak is shifted towards late spring/early summer in the $\mathrm{NH}$ and towards winter in the SH. As Roelofs and Lelieveld (1997) reported, the seasonal timing of the input of stratospheric ozone into the troposphere is relevant for potential mixing of stratospheric ozone towards the surface, as in summer the ozone loss rate is larger than in winter. This means that the future distribution of stratospheric ozone in the troposphere depends not only on the overall increase of OMF, but also on the seasonality of the input.

The aim of our study is, therefore, to quantify the future changes of STE in simulations with a chemistry-climate model (CCM) under the most extreme RCP8.5 scenario for the annual and monthly means. We identify the changes in the seasonal cycle of STE due to the projected increase in GHGs and decline in ODS, i.e., the associated stratospheric ozone recovery. Furthermore, we analyze the resulting changes in the distribution of stratospheric ozone in the troposphere, using comprehensive stratospheric and tropospheric chemistry. We thus consider the full range of changes 
in chemical loss and production caused by GHG or ODS changes. By analyzing an additional transient simulation run under the RCP6.0 scenario we are able to assess the different effects of a moderate and a strong GHG scenario on the future OMF and trends of stratospheric ozone in the troposphere.

In this study we consequently want to address the following research questions:

1. How will the stratosphere-to-troposphere OMF change in the future?

2. What are the major drivers of future changes in the stratosphere-to-troposphere OMF?

3. Will the seasonality of the STE change in the future?

4. How will GHG emission scenarios affect the OMF into the troposphere?

5. How is the ratio of stratospheric ozone in the troposphere changed in the future?

The study is structured as follows: first the model and the experimental setup used for the simulations are described as well as the methodology for calculating the OMF from the stratosphere to the troposphere (Sect. 2). In Sect. 3 we show the climatological mean state of the year 2000 simulation for a basic evaluation. The results of mass flux changes and changes in the distribution of stratospheric ozone in the troposphere are shown in Sect. 4 followed by the attribution analysis in Sect. 5. Finally, the results are summarized in Sect. 6.

\section{Model experiments and methods}

\subsection{Model experiments}

In this study we applied the EMAC (ECHAM/MESSy Atmospheric Chemistry) CCM version described by Jöckel et al. (2016) in the T42L47MA configuration, i.e., with 47 model layers and a horizontal resolution of $2.8^{\circ} \times 2.8^{\circ}$. EMAC is a numerical chemistry and climate simulation system that includes submodels describing tropospheric and middle atmosphere processes and their interaction with oceans, land, and human influences (Jöckel et al., 2016). It uses the second version of the Modular Earth Submodel System (MESSy2) to link multi-institutional computer codes. The core atmospheric model is the 5th-generation European Centre Hamburg general circulation model (ECHAM5) (Roeckner et al., 2006). The atmospheric chemistry is calculated using the submodule MECCA (Module Efficiently Calculating the Chemistry of the Atmosphere; revised version by R. Sander et al., 2011). The gas-phase rate coefficients follow the latest recommendations of JPL (S. P. Sander et al., 2011). For heterogeneous reactions in the stratosphere the rate coefficients are calculated with the submodel MSBM
(Multi-phase Stratospheric Box Model) which also returns the parameters (e.g., number densities, surface areas) of the sulfuric acid aerosols and the polar stratospheric cloud (PSC) particles.

To quantify the impact of increasing GHG concentrations and of declining stratospheric halogen levels on the net OMF from the stratosphere into the troposphere, we performed four experiments in time-slice mode, i.e., with non-varying boundary conditions from year to year, but including a seasonal cycle. In addition to reference simulations for the years 2000 and 2100, one sensitivity simulation for GHG increase only and one for ODS decrease only have been set up. Each time-slice simulation was integrated over 40 years following a 5 year spin-up time. Future surface concentrations of the well-mixed GHGs $\left(\mathrm{CO}_{2}, \mathrm{~N}_{2} \mathrm{O}, \mathrm{CH}_{4}\right)$ are prescribed according to the extreme RCP8.5 scenario (Meinshausen et al., 2011) in order to reveal the upper boundary of the anticipated future changes. They are coupled to both the radiation and chemistry schemes of the model. The changes in tropospheric ozone precursor species (such as nitrogen monoxide (NO), carbon monoxide (CO), methane $\left(\mathrm{CH}_{4}\right)$, and nonmethane volatile organic compounds (NMVOCs) also follow the RCP8.5 emission scenario and are included in the reference simulation for the year 2100 . Since $\mathrm{CH}_{4}$ acts as both a GHG and tropospheric ozone precursor, a clear separation of the effects via the prescription of surface boundary conditions in a model run is not possible. Therefore, for the GHG sensitivity simulation the non-methane precursor compounds are fixed at the year 2000 level (see Table 2) whereas $\mathrm{CH}_{4}$ is increasing. Although the RCP scenarios project the surface emissions of $\mathrm{NO}_{x}, \mathrm{CO}$, and NMVOCs in the year 2100 to be lower than in the year 2000, the strong increase in $\mathrm{CH}_{4}$ concentrations (more than doubling in the RCP8.5) will lead to an increased tropospheric ozone production by the end of the 21 st century which is attributed to the GHG change in this study.

The estimated decline of ODS as a consequence of the successful regulation of halogen containing species in the Montreal Protocol and its amendments is given by the boundary conditions following the A1 scenario in WMO (2011). Note that due to the unintended neglect of minor chlorine source gases CFC-113, CFC-144, CFC-155 as well as HCFC-22, HCFC-141b, and HCFC-142b, stratospheric chlorine levels in the year 2000 are underestimated by about $10 \%$.

The quasi-biennial oscillation (QBO) of tropical winds in the stratosphere is nudged to observations following Giorgetta and Bengtsson (1999). Solar variability like the 11 year solar cycle is not included, instead solar mean conditions of solar cycle number 22 are prescribed. The sea surface temperature (SST) and sea ice concentration (SIC) fields are prescribed as 10 year averages around the respective years using the output from a transient simulation with the coupled atmosphere ocean model MPI-ESM (Max-Planck-Institute Earth System Model; Giorgetta et al., 2013; Schmidt et al., 2013) for the RCP8.5 scenario. Using multi-year averages reduces 
Table 1. EMAC CCM simulations used in this study.

\begin{tabular}{llllll}
\hline Name & Run mode & $\begin{array}{l}\mathrm{GHG} \\
\left(\mathrm{CO}_{2}, \mathrm{CH}_{4},\right. \\
\left.\mathrm{N}_{2} \mathrm{O}\right)\end{array}$ & $\begin{array}{l}\text { Tropos. } \mathrm{O}_{3} \\
\text { precursor } \\
\left(\mathrm{CO}, \mathrm{NO}_{x},\right. \\
\text { NMVOCs })\end{array}$ & ODS & SST/SIC \\
\hline $\begin{array}{l}\text { RCP6.0 (referred to as } \\
\text { RC2-base-05 in } \\
\text { Jöckel et al., 2016) }\end{array}$ & $\begin{array}{l}\text { Transient (1960-2099, } \\
\text { after a 10 year spin-up) }\end{array}$ & RCP6.0 & RCP6.0 & $\begin{array}{l}\text { Observations } \\
\text { and A1 }\end{array}$ & $\begin{array}{l}\text { HadGEM } \\
1960-2099\end{array}$ \\
\hline REF2000 & Time slice (40 years, & $\begin{array}{l}\text { Observations } \\
\text { for 2000 }\end{array}$ & $\begin{array}{l}\text { Observations } \\
\text { for 2000 }\end{array}$ & $\begin{array}{l}\text { Observations } \\
\text { for 2000 }\end{array}$ & $\begin{array}{l}\text { MPI-ESM } \\
1995-2004\end{array}$ \\
\hline REF2100 & $\begin{array}{l}\text { Time slice (40 years, } \\
\text { after a 5 year spin-up) }\end{array}$ & $\begin{array}{l}\text { RCP8.5 } \\
\text { for 2100 }\end{array}$ & $\begin{array}{l}\text { RCP8.5 } \\
\text { for 2100 }\end{array}$ & A1 for 2100 & $\begin{array}{l}\text { MPI-ESM } \\
2095-2104\end{array}$ \\
\hline GHG2100 & $\begin{array}{l}\text { Time slice (40 years, } \\
\text { after a 5 year spin-up) }\end{array}$ & $\begin{array}{l}\text { RCP8.5 } \\
\text { for 2100 }\end{array}$ & $\begin{array}{l}\text { Observations } \\
\text { for 2000 }\end{array}$ & Obs. for 2000 & $\begin{array}{l}\text { MPI-ESM } \\
2095-2104\end{array}$ \\
\hline ODS2100 & $\begin{array}{l}\text { Time slice (40 years, } \\
\text { after a 5 year spin-up) }\end{array}$ & $\begin{array}{l}\text { Observations } \\
\text { for 2000 }\end{array}$ & $\begin{array}{l}\text { Observations } \\
\text { for 2000 }\end{array}$ & A1 for 2100 & $\begin{array}{l}\text { MPI-ESM } \\
1995-2004\end{array}$
\end{tabular}

the interannual variability of the SSTs, but ensures quasi neutral conditions of the El Niño - Southern Oscillation (ENSO). An overview of the boundary conditions in the four simulations is given in Table 1 . The chosen setup of the simulations allows us to separate the combined effect of the $\mathrm{CO}_{2}, \mathrm{~N}_{2} \mathrm{O}$, and $\mathrm{CH}_{4}$ increase from the ODS effect on the future OMF. It has to be noted that the GHG-induced changes in this study include all GHG-related effects on stratospheric chemistry and dynamics, and the contributions from GHG-induced climate change cannot be separated from the impact of $\mathrm{CH}_{4}$ and $\mathrm{N}_{2} \mathrm{O}$ related changes in the ozone chemistry.

To show the temporal evolution of the changes and to compare the effects for different GHG scenarios we also analyze the model output from the transient simulation RC2-base05 of the Earth System Chemistry integrated Modelling (ESCiMo) project (Jöckel et al., 2016) which has been integrated according to the RCP6.0 scenario from 1960 to 2100 following a 10 year spin-up. The SST and SIC fields for the RCP6.0 scenario are prescribed from the Hadley Centre Global Environment Model version 2 - Earth System (HadGEM2-ES) Model (Collins et al., 2011; Martin et al., 2011). The boundary conditions for this simulation are given in Table 1. More detailed information of this simulation can be found in Jöckel et al. (2016). Note that consistent SSTs/SICs from a MPIESM RCP6.0 simulation were not available. Potential effects of the different SST datasets are discussed in Sect. 4. It also has to be noted that the stratospheric ozone loss in the past is underestimated in this simulation, which affects the trends in OMF.

\subsection{Methods}

To quantify the net OMF from the stratosphere into the troposphere we follow the approach described by Hegglin and
Shepherd (2009), which is an extension to the box model approach by Appenzeller et al. (1996). Appenzeller et al. (1996) described the hemispheric net mass transport in a simple model which consists of three regions (i.e., boxes), the troposphere, the "lowermost stratosphere" (LMS), and the "overworld". The LMS is the region where isentropic surfaces intersect the tropopause. Thus mass can be exchanged between the stratosphere and the troposphere along such isentropic surfaces. Above the LMS, often referred to as the overworld according to Holton et al. (1995), the isentropic surfaces lie entirely in the stratosphere and mass exchange is only possible by cross-isentropic transport, which is carried out by the large-scale meridional circulation in the stratosphere (BDC). Due to mass continuity, a mass flux from the overworld into the LMS $\left(F_{\text {in }}\right)$ must be balanced by a mass flux out of the LMS $\left(F_{\text {out }}\right)$ and/or mass change $(\mathrm{d} M / \mathrm{d} t)$ in the LMS:

$F_{\text {in }}=F_{\text {out }}+\mathrm{d} M / \mathrm{d} t$.

In our study we use the $91 \mathrm{hPa}$ surface (nearest pressure level of the model output to $100 \mathrm{hPa}$ ) as the upper boundary for the LMS box model and the model tropopause (a combination of the thermal tropopause in the tropics and the dynamical tropopause in the extratropics) as lower boundary, analogously to Hegglin and Shepherd (2009). Thus, $M$ in Eq. (1) is the total ozone mass between these boundaries, and $\mathrm{dM} / \mathrm{dt}$ is the monthly change of $M . F_{\text {in }}$ is calculated for each hemisphere as the area-weighted integral of the product of the monthly zonal mean ozone concentration and the negative of the monthly mean residual vertical velocity $\left(-\bar{w}^{*}\right)$ at $91 \mathrm{hPa}$ at each grid point. Since, by definition, the vertical velocity is positive for upward and negative for downward motion, $\bar{w}^{*}$ is multiplied by the factor -1 in order to get positive values for the downward OMF into the troposphere. Finally, $F_{\text {out }}$ is calculated as residual. It has to be noted that 

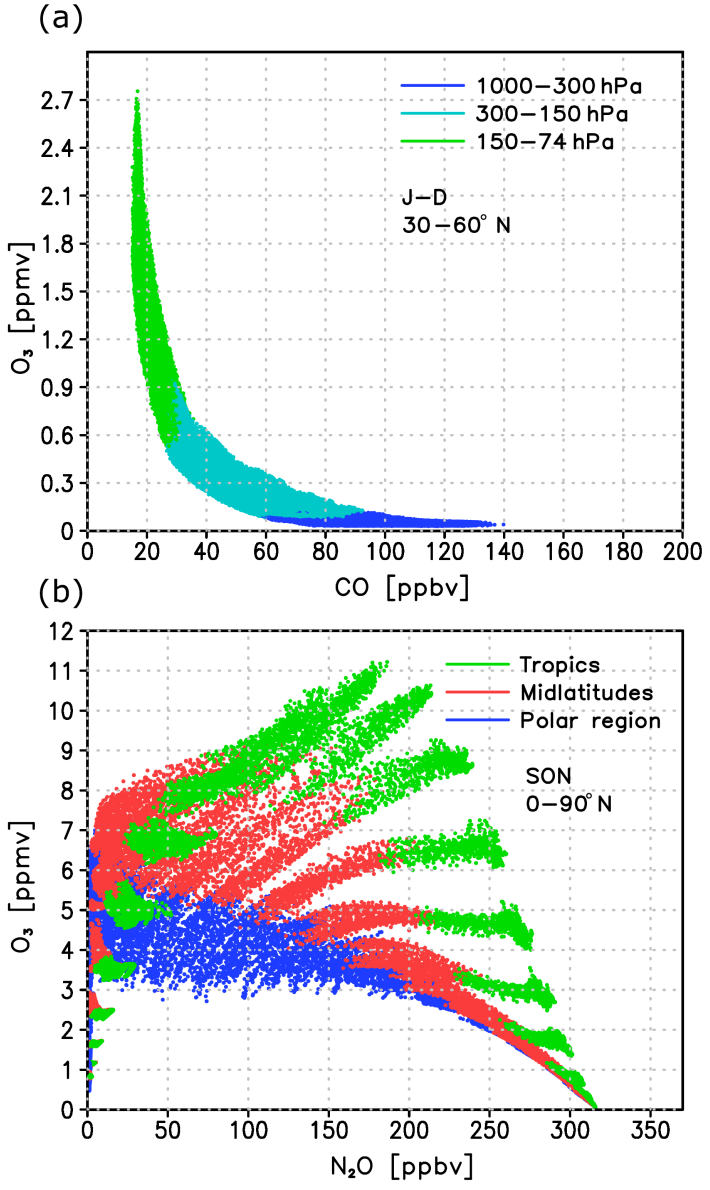

Figure 1. (a) $\mathrm{O}_{3}-\mathrm{CO}$ scatter plot for January to December in the latitude band $30-60^{\circ} \mathrm{N}$ for the REF2000 simulation from the troposphere to the lower stratosphere. Color coding indicates different height regions. (b) $\mathrm{O}_{3}-\mathrm{N}_{2} \mathrm{O}$ scatter plot for September to November in the Northern Hemisphere for the REF2000 simulation at the altitude region between 270 and $0.1 \mathrm{hPa}$. Color coding indicates different latitude bands.

with this methodology it is not possible to study the transport pathways. The use of the $91 \mathrm{hPa}$ surface as upper boundary instead of $100 \mathrm{hPa}$ leads to slightly lower values of the resulting OMF $(<2 \%$ in the REF2000 simulation, which is an estimation based on linear interpolation between the two model pressure surfaces surrounding $100 \mathrm{hPa}$ ).

To distinguish ozone with stratospheric origin $\left(\mathrm{O}_{3} \mathrm{~s}\right)$ and ozone produced in the troposphere $\left(\mathrm{O}_{3} \mathrm{t}\right)$ we use a diagnostic tracer (Roelofs and Lelieveld, 1997; Collins et al., 2003; Jöckel et al., 2016). This tracer is reset in each model time step (by nudging with a relaxation time equaling the model time step length) to the interactive ozone above the model tropopause. In the troposphere the chemical production of $\mathrm{O}_{3} \mathrm{~s}$ is omitted, while the sinks of $\mathrm{O}_{3}$ s, i.e., chemical loss and dry deposition are considered in the same way as for $\mathrm{O}_{3}$. The statistical significance of the future changes is tested by applying the Student's $t$ test.

\section{Equilibrium state of the year 2000 (REF2000)}

Before we estimate the future change in OMF into the troposphere, the present-day equilibrium state is analyzed to ensure that the important mixing processes and tracer distributions are represented realistically in the EMAC simulations. An effective method to investigate STE and mixing processes in the LMS are tracer-tracer correlations.

\subsection{Tracer-tracer correlations from scatter plots}

Fischer et al. (2000) introduced the $\mathrm{O}_{3}-\mathrm{CO}$ correlations for aircraft in situ measurements to analyze the chemical transition between the stratosphere and troposphere and the mixing processes in the upper troposphere-lower stratosphere (UTLS). Due to the sharp gradients with high $\mathrm{CO}\left(\right.$ low $\left.\mathrm{O}_{3}\right)$ values in the upper troposphere and low $\mathrm{CO}\left(\right.$ high $\left.\mathrm{O}_{3}\right)$ values in the lower stratosphere, the $\mathrm{O}_{3}-\mathrm{CO}$ scatter plot has a characteristic L-shape in the UTLS (e.g., Fischer et al., 2000; Tian et al., 2010; Barré et al., 2013). Pan et al. (2007) distinguish the stratospheric branch and the tropospheric branch with a quasi linear relation between $\mathrm{O}_{3}$ and $\mathrm{CO}$ and a transition region in between characterized by non-linear behavior. Figure 1a shows the $\mathrm{O}_{3}-\mathrm{CO}$ scatter plot for the REF2000 simulation in the northern middle latitudes. Compared to the correlations shown by Fischer et al. (2000) (derived from aircraft measurements) and by Hegglin et al. (2009) (derived from ACE-FTS measurements) we find that the L-shape of the correlation is captured well by the EMAC time-slice simulation.

The shape of the $\mathrm{O}_{3}-\mathrm{N}_{2} \mathrm{O}$ scatter plot (Fig. 1b) with a full stratosphere coverage results from the negative vertical gradient in $\mathrm{N}_{2} \mathrm{O}$ and the $\mathrm{O}_{3}$ maximum in the stratosphere: the correlation is negative below the ozone maximum and positive above. The fan-shaped structure is due to the horizontal gradient with higher $\mathrm{O}_{3}$ and $\mathrm{N}_{2} \mathrm{O}$ values in the tropics than in the extratropics. The model result is in qualitative agreement with $\mathrm{O}_{3}-\mathrm{N}_{2} \mathrm{O}$ scatter plots for ACE measurements shown by Hegglin and Shepherd (2007).

This comparison indicates that the dynamical and chemical processes in the transition region between the troposphere and stratosphere are realistic in the EMAC time-slice simulations and allows us to assess the future changes.

\subsection{Ozone mass flux (OMF)}

The annual cycle of the OMF into the troposphere ( $F_{\text {out }}$, calculated according Eq. 1) for the year 2000 reference simulation is shown in Fig. 2a, integrated globally and over the $\mathrm{NH}$ and $\mathrm{SH}$ respectively. The OMF into the NH has its peak in early summer (June), whereas in the SH the maximum OMF is found in spring (October). The annual cycle in the EMAC 

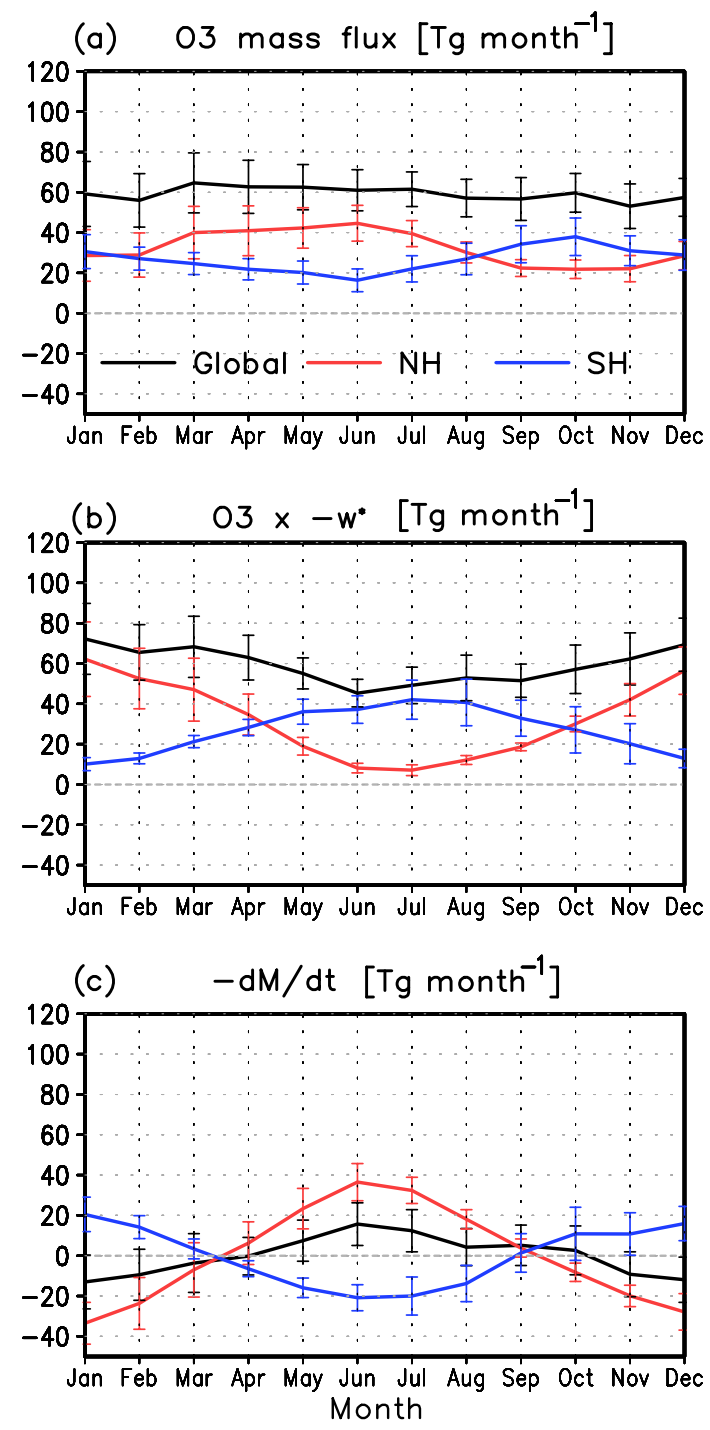

Figure 2. (a) Annual ozone mass flux and its $95 \%$ confidence interval (i.e., $\pm 2 \sigma$, where $\sigma$ is standard deviation) $\left[\mathrm{Tg}\right.$ month $\left.^{-1}\right]$ from the stratosphere into the troposphere $\left(F_{\text {out }}\right)$ in the REF2000 simulation integrated globally (black), over the Northern Hemisphere (red) and the Southern Hemisphere (blue). (b) Same as (a) but for $F_{\text {in }}$ (the product between the ozone concentration and the negative zonal mean residual vertical velocity $\bar{w}^{*}$ at $91 \mathrm{hPa}$ ). (c) Same as (a) but for the negative monthly change in ozone mass of the LMS $(-\mathrm{d} M / \mathrm{d} t)$, also referred to as seasonal breathing.

REF2000 simulation is comparable to the results of Hegglin and Shepherd (2009) for the period 1960 to 1970, but with a less pronounced peak in the NH spring in EMAC.

Integrated over all months, the OMF in the EMAC REF2000 time-slice simulation reaches $390 \pm 18$ Tg year $^{-1}$ in the $\mathrm{NH}, \quad 322 \pm 16 \mathrm{Tg} y e a r^{-1}$ in the $\mathrm{SH}$, and $712 \pm 26 \mathrm{Tg}$ year $^{-1}$ globally. Compared to estimates derived from observations $\left(540 \pm 140 \mathrm{Tg}_{\text {year }}{ }^{-1}\right.$; Olsen et al., 2001; Wild, 2007), the global OMF is slightly overestimated in
EMAC, however, within the range of 340-1440 $\mathrm{Tg}^{\text {year }}{ }^{-1}$ given by Wild (2007) for a number of models. The STE OMF in EMAC hits the upper boundary of the OMF derived from the Atmospheric Composition Change: the European Network of Excellence (ACCENT) tropospheric model intercomparison for the year $2000\left(552 \pm 168 \mathrm{Tg}\right.$ year $\left.^{-1}\right)$ (Stevenson et al., 2006), while the mean net STE OMF from six models of the Atmospheric Chemistry and Climate Model Intercomparison Project (ACCMIP) was lower (477 $\pm 96 \mathrm{Tg}_{\text {year }}{ }^{-1}$; Young et al., 2013). The estimated STE OMFs generally show a large range as they strongly depend on various factors, such as the prescribed ozone precursors, the horizontal and vertical resolution of the applied models, the definition of the tropopause, or the degree of chemical processes considered in the models. Hegglin and Shepherd (2009), using a middle atmosphere resolving CCM with full chemistry - comparable in complexity to the EMAC CCM used in this study - derived a global STE ozone flux of $655 \pm 5 \mathrm{Tg}_{\mathrm{gear}}{ }^{-1}$ averaged over the 1995 to 2005 period of a transient simulation.

To better understand the changes in the calculated OMF $\left(F_{\text {out }}=F_{\text {in }}-\mathrm{d} M / \mathrm{d} t\right)$, we analyze the climatological annual cycle of the two OMF components, $F_{\text {in }}$ at $91 \mathrm{hPa}$ (Fig. 2b) and $-\mathrm{d} M / \mathrm{d} t$ (Fig. 2c). The OMF across the $91 \mathrm{hPa}$ pressure level is controlled by the seasonality of the BDC with the maximum (ozone) net mass flux into the LMS in the winter hemisphere and a hemispherically asymmetric strength (Fig. 2b). The ozone distribution in the stratosphere (see also Fig. 3a), with low columns in the tropics and high columns in the middle and high latitudes, also reflects the structure of the stratospheric meridional circulation. The seasonal breathing of the LMS (Fig. 2c) leads to a shift of the high OMF phase from winter to spring and early summer (which is consistent with Hegglin and Shepherd, 2009) and of the low OMF phase from summer to autumn. The amplitude of the seasonal cycle in $-\mathrm{d} M / \mathrm{d} t$ is slightly larger in the $\mathrm{NH}$ than in the $\mathrm{SH}$ which dampens the amplitude of the OMF in the $\mathrm{NH}$.

The timing of the maximum OMF into the troposphere is relevant for the resulting downward mixing since the chemical lifetime of tropospheric ozone in the mid- and highlatitudes has a pronounced seasonal cycle with short lifetimes in the summer and relatively long lifetimes in winter and spring. This means that ozone can be mixed more efficiently with tropospheric air masses in winter and spring (Roelofs and Lelieveld, 1997) although the ozone influx from the stratosphere is smaller in northern early spring than in summer.

In the next section we analyze the abundance of ozone with stratospheric origin $\left(\mathrm{O}_{3} \mathrm{~s}\right)$ in the troposphere for June (Fig. 3), when the OMF is maximal in the $\mathrm{NH}$ and minimal in the SH (Fig. 2a). 
(a)
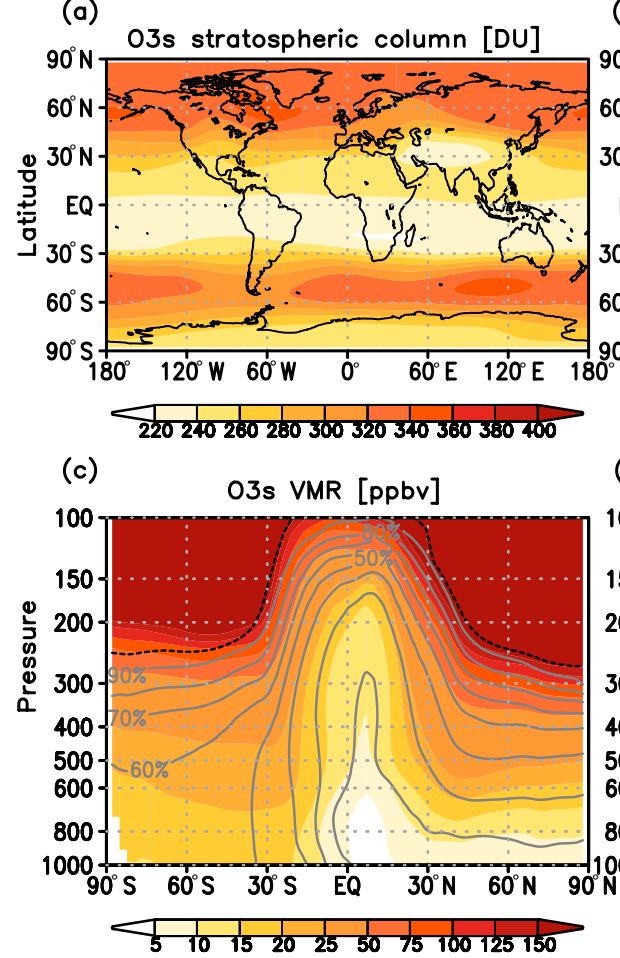

(b)

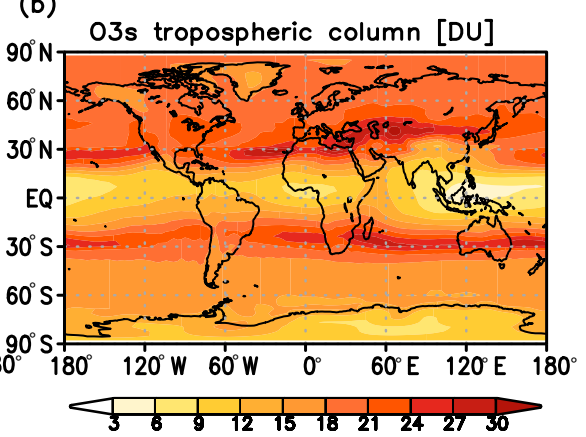

(d)

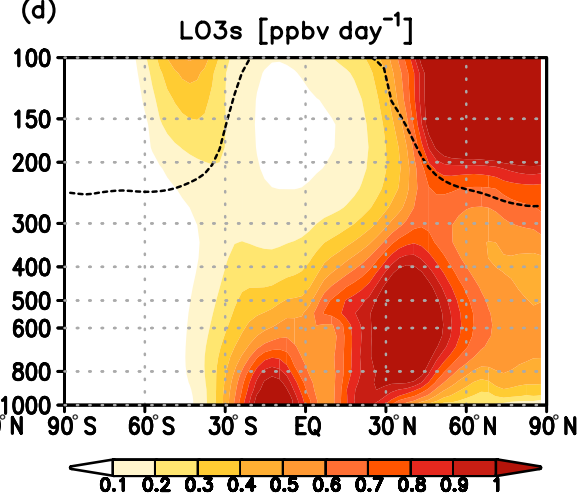

Figure 3. (a) Geographical distribution of stratospheric partial columns of the diagnostic $\mathrm{O}_{3}$ s tracer in Dobson units (DU) in June for the REF2000 simulation. (b) Same as (a) but for tropospheric columns. (c) Latitude-height section of the $\mathrm{O}_{3}$ s volume mixing ratios [ppbv] and (d) latitude-height section of the chemical loss rate of $\mathrm{O}_{3} \mathrm{~s}$ [ppbv day ${ }^{-1}$ ]. The black dashed line indicates the position of the mean tropopause. Gray contour lines in (c) show the relative contribution of $\mathrm{O}_{3} \mathrm{~s}$ to the ozone field in percent.

\subsection{Stratospheric ozone in the troposphere}

The column-aggregated stratospheric ozone in the troposphere (Fig. 3b) reaches a maximum of $30 \mathrm{DU}$ around $30^{\circ}$ in both hemispheres and a minimum in the tropics (3-6 DU over Indonesia) and the southern high latitudes. The low values in the tropics presumably result from very short ozone lifetimes near the surface as the high insolation and high water vapor concentrations in the intertropical convergence zone (ITCZ) form a strong sink for ozone in the troposphere (Roelofs and Lelieveld, 1997). In addition, the downward transport of stratospheric ozone in the tropics is very small due to the upward branch of the BDC in this region. The high tropospheric $\mathrm{O}_{3}$ s columns in the subtropics result from high abundances of stratospheric ozone in the upper troposphere, especially in the NH subtropics, which is evident in Fig. 3c. Here, ozone entering the troposphere through tropopause folds is efficiently transported to lower altitudes in the downward branch of the Hadley cell (Roelofs and Lelieveld, 1997) resulting in relatively high $\mathrm{O}_{3}$ s levels in the middle troposphere around $30^{\circ} \mathrm{N}$. The $\mathrm{O}_{3}$ s mixing ratios decrease with lower altitude and reach their minimum near the surface, with the smallest values in the tropics and the $\mathrm{NH}$, as ozone loss is largest in summer (Fig. 3d). However, ozone originating from the stratosphere is also found down to the lower troposphere in the extratropics. This may be caused by events where stratospheric air penetrates deep into the troposphere and affects also lower levels (e.g., Škerlak et al., 2014).

The contribution of $\mathrm{O}_{3}$ s to $\mathrm{O}_{3}\left(=\mathrm{O}_{3} \mathrm{~s}+\mathrm{O}_{3} \mathrm{t}\right)$ ranges between $20 \%$ in the tropics and the $\mathrm{NH}$ lower troposphere and (up to) $40 \%$ in the middle troposphere $(500 \mathrm{hPa}$ ) in the $\mathrm{NH}$. In the $\mathrm{SH}$, the relative contribution of $\mathrm{O}_{3} \mathrm{~S}$ to $\mathrm{O}_{3}$ is larger (50-60\% near the surface and more than $60 \%$ at $500 \mathrm{hPa}$ at high latitudes). This is caused by the lower chemical loss of $\mathrm{O}_{3} \mathrm{~s}$ in winter (Fig. 3d) in combination with the smaller chemical production of tropospheric ozone in this season. In the SH summer this pattern is reversed (not shown), however, with a slightly larger contribution of $\mathrm{O}_{3}$ s near the $\mathrm{SH}$ surface (20-30\%) compared to the NH summer. This is possibly related to the lower local photochemical ozone production in the SH due to reduced emissions and abundances of tropospheric ozone precursor species.

In summary, we have found realistic tracer distributions in the tropopause region of the EMAC reference simulation for the year 2000. The OMF appears to be overestimated compared to observations and other model studies. However, given the large uncertainties for estimates from observational data and the range of different model types, the OMF in 


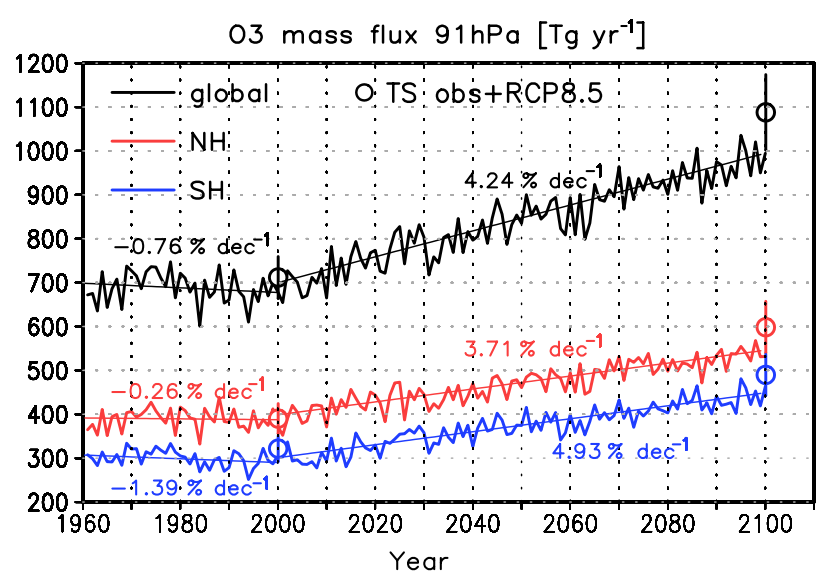

Figure 4. Temporal evolution of the ozone mass flux [Tg year ${ }^{-1}$ ] into the troposphere from 1960 to 2099 in the transient RCP6.0 simulation integrated globally (black), over the Northern Hemisphere (red), and the Southern Hemisphere (blue). The thin lines indicate the linear fits for the sub-periods 1960 to 2000 and 2000 to 2099. In addition, the ozone mass fluxes derived from the time-slice simulations (TS) for the years 2000 (REF2000) and 2100 (REF2100, RCP8.5 scenario) are shown by open circles including the $\pm 2 \sigma$ range.

EMAC can be regarded as reasonable. The results indicate that the important processes determining the STE are sufficiently well reproduced by EMAC, which allows us to study the past and future changes of the OMF as well as the contributions from GHG and ODS changes in the next section.

\section{Past and future changes in OMF into the troposphere}

Changes in the input of stratospheric ozone into the troposphere can be caused by changes in the dynamical processes and/or by the amount of ozone that is available for transport in the stratosphere. Thus, not only may GHG concentrations have an impact on the stratosphere-to-troposphere transport but also on the development of the ODS. The evolution of the integrated OMF between 1960 and 2099 for the RCP6.0 simulation, which includes the observed and projected ODS and GHG changes as well as the increase in tropospheric ozone precursor concentrations, is shown in Fig. 4. In the past (1960-1999), the integrated OMF exhibited a negative trend in both hemispheres with a larger change of $-1.4 \%$ per decade in the $\mathrm{SH}$ which is in qualitative agreement with, but smaller than, the trend $(-2.3 \%$ per decade) found by Hegglin and Shepherd (2009) between 1965 and 2000. Zeng et al. (2010) showed that this negative trend is associated with the ODS-induced ozone loss in the stratosphere which is most prominent in the southern polar region in spring. Between 2000 and 2099 the OMF is projected to increase globally by $4.2 \%$ per decade. Again, the change in the $\mathrm{SH}$ (4.9\% per decade) is slightly larger than in the $\mathrm{NH}$
( $3.7 \%$ per decade). This increase may be ascribed to different forcings: (1) the regulations of ODS emissions lead to a decline of chlorine in the stratosphere and increasing stratospheric ozone levels; (2) the increasing GHG concentrations alter the temperature structure of the atmosphere and intensify the large-scale mass transport in the stratosphere; and (3) the radiative cooling of the stratosphere due to increasing GHG concentrations slows chemical loss reactions, which increases the ozone amount in the stratosphere. To understand the impact of ODS and GHG changes on the OMF in more detail, we further analyze the sensitivity simulations following the RCP8.5 scenario. For comparison the reference timeslice simulations for the years 2000 and 2100 are included in Fig. 4. The 1995-2004 average in the RCP6.0 simulation gives an OMF of $688 \pm 24 \mathrm{Tg}_{\text {year }}{ }^{-1}$ which is slightly lower than in the time-slice simulation for 2000, but within the range of two standard deviations of the REF2000 simulation. This difference might be due to the reduced variability in the time-slice simulation compared to the transient simulation (see Sect. 2), and/or due to the different SST/SIC fields used in the simulations. However, the results of the model simulations are in relatively good agreement.

In the future, the OMF is clearly larger in the time-slice simulations than in the transient simulation due to the climate change- and methane-related effects of the more extreme GHG emission scenario (RCP8.5 compared to RCP6.0). The integrated OMF reaches $598 \pm 29 \mathrm{Tg}$ year $^{-1}$ in the NH, $490 \pm 23 \mathrm{Tg}_{\text {year }}{ }^{-1}$ in the $\mathrm{SH}$, and $1088 \pm 43 \mathrm{Tg} \mathrm{year}^{-1}$ for the global sum. This corresponds to a relative increase of 5.3, 5.2 , and $5.3 \%$ per decade, respectively (see also Table 2). Thus, while in the RCP6.0 scenario, the OMF increase by the end of the century is stronger in the $\mathrm{SH}$ than in the $\mathrm{NH}$ due to the prevailing impact of stratospheric ozone recovery in the $\mathrm{SH}, \mathrm{OMF}$ increases are of similar magnitude in both hemispheres for the RCP8.5 GHG scenario. This is due to the growing role of an increased BDC in the RCP8.5 scenario which has a stronger impact in the NH. Note that the difference in OMF change by 2100 between the time-slice and transient simulations may not be due to the different GHG scenario alone. The HadGEM2-ES model which provided the SST/SIC distribution for the transient RCP6.0 simulation is known to have a higher climate sensitivity than the MPIESM which provided the SST/SICs for the EMAC time-slice runs (Andrews et al., 2012). This might lead to a somewhat stronger future SST increase, STE, and OMF in the transient RCP6.0 run than would arise using MPI-ESM SSTs/SICs. Hence, the differences in OMF by 2100 discussed here represent a lower boundary estimate of the expected OMF differences between the RCP6.0 and RCP8.5 scenarios. 

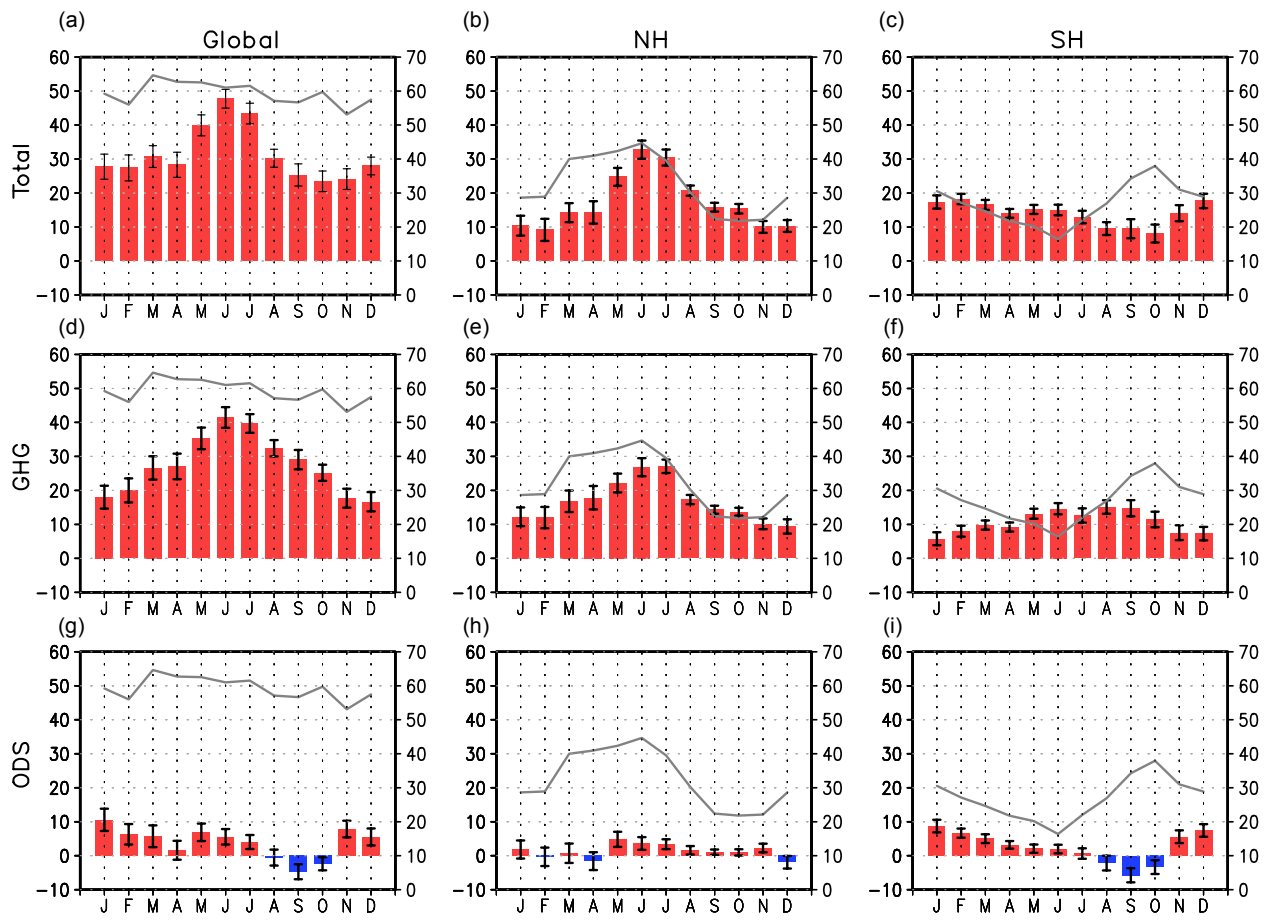

Figure 5. Annual cycle of ozone mass flux changes between 2000 and 2100 [ $\mathrm{Tg} \mathrm{month}^{-1}$ ] in the time-slice simulations integrated globally $(\mathbf{a}, \mathbf{d}, \mathbf{g})$, over the Northern Hemisphere $(\mathbf{b}, \mathbf{e}, \mathbf{h})$, and over the Southern Hemisphere $(\mathbf{c}, \mathbf{f}, \mathbf{i})$ for the changes due to all forcings $(\mathbf{a}-\mathbf{c})$, for the effect of increasing GHG concentrations (d-f) and for the impact of declining ODS levels (g-i). The black error bars denote $\pm 2 \sigma$. The absolute ozone mass flux of the reference simulation REF2000 is shown as grey line with the corresponding $y$ axis on the right.

Table 2. Overview of the annual ozone mass flux into the troposphere and the corresponding standard deviations in the EMAC time-slice simulations. Bold numbers indicate the change relative to the REF2000 simulation. All changes are significant at the $95 \%$ confidence level.

\begin{tabular}{rrrr}
\hline & \multicolumn{3}{c}{$\mathrm{O}_{3}$ mass flux $\left[\mathrm{Tg} \mathrm{yr}^{-1}\right]$} \\
\cline { 2 - 4 } & Global mean & $\mathrm{NH}$ & $\mathrm{SH}$ \\
\hline REF2000 & $712 \pm 26$ & $390 \pm 18$ & $322 \pm 16$ \\
\hline REF2100 & $1088 \pm 43$ & $598 \pm 29$ & $490 \pm 23$ \\
& $+\mathbf{5 3 \%}$ & $+\mathbf{5 3 \%}$ & $+\mathbf{5 2} \%$ \\
\hline GHG2100 & $1041 \pm 36$ & $590 \pm 28$ & $451 \pm 26$ \\
& $+\mathbf{4 6 \%}$ & $+\mathbf{5 1} \%$ & $+\mathbf{4 0} \%$ \\
\hline ODS2100 & $\mathbf{7 5 8 \pm 2 6}$ & $406 \pm 20$ & $352 \pm 13$ \\
& $+\mathbf{7 \%}$ & $\mathbf{+ 4 \%}$ & $\mathbf{+ 9 \%}$ \\
\hline
\end{tabular}

\section{Attribution of future changes in OMF to climate change}

Figure 5 shows the monthly changes of the OMF for the sensitivity simulations, i.e., for the total change between 2000 and 2100 due to all forcings and the changes resulting from GHG and ODS changes only. It has to be noted that the changes due to GHGs and ODS do not necessarily sum up to the total change due to non-linear interactions and due to the fact that the change in non-methane tropospheric ozone precursor species is only included in the reference simulation for 2100 (see Table 1). However, in the RCP8.5 scenario the largest changes in ozone precursors are for methane which are included in the GHG signal. Nevertheless, the effect of the projected increase in tropospheric ozone precursor concentrations on the OMF change between 2000 and 2100 cannot be unambiguously separated from the total change in this study. This is also due to the impact of the non-methane ozone precursors on ozone production in the lower stratosphere and the tropospheric ozone loss, which can affect the OMF as well as the $\mathrm{O}_{3}$ s distribution in the troposphere. While all these interactions are taken into account in the future reference simulation, the objective of the sensitivity runs is to simplify the complexity and to focus on the changes driven by the well-mixed GHGs and the ODS. Furthermore, all results shown for the GHG-induced signal in the OMF consist of both the contribution from a strengthened BDC and the chemically driven (climate and $\mathrm{CH}_{4}$ related) increase in stratospheric ozone available for downward transport.

The change in OMF between 2000 and 2100 due to all forcings (Fig. 5a-c) is positive throughout the year with maximal increases in the summer months of the respective hemispheres by up to $32 \mathrm{Tg}$ month $^{-1}(75 \%)$ in the $\mathrm{NH}$ and 

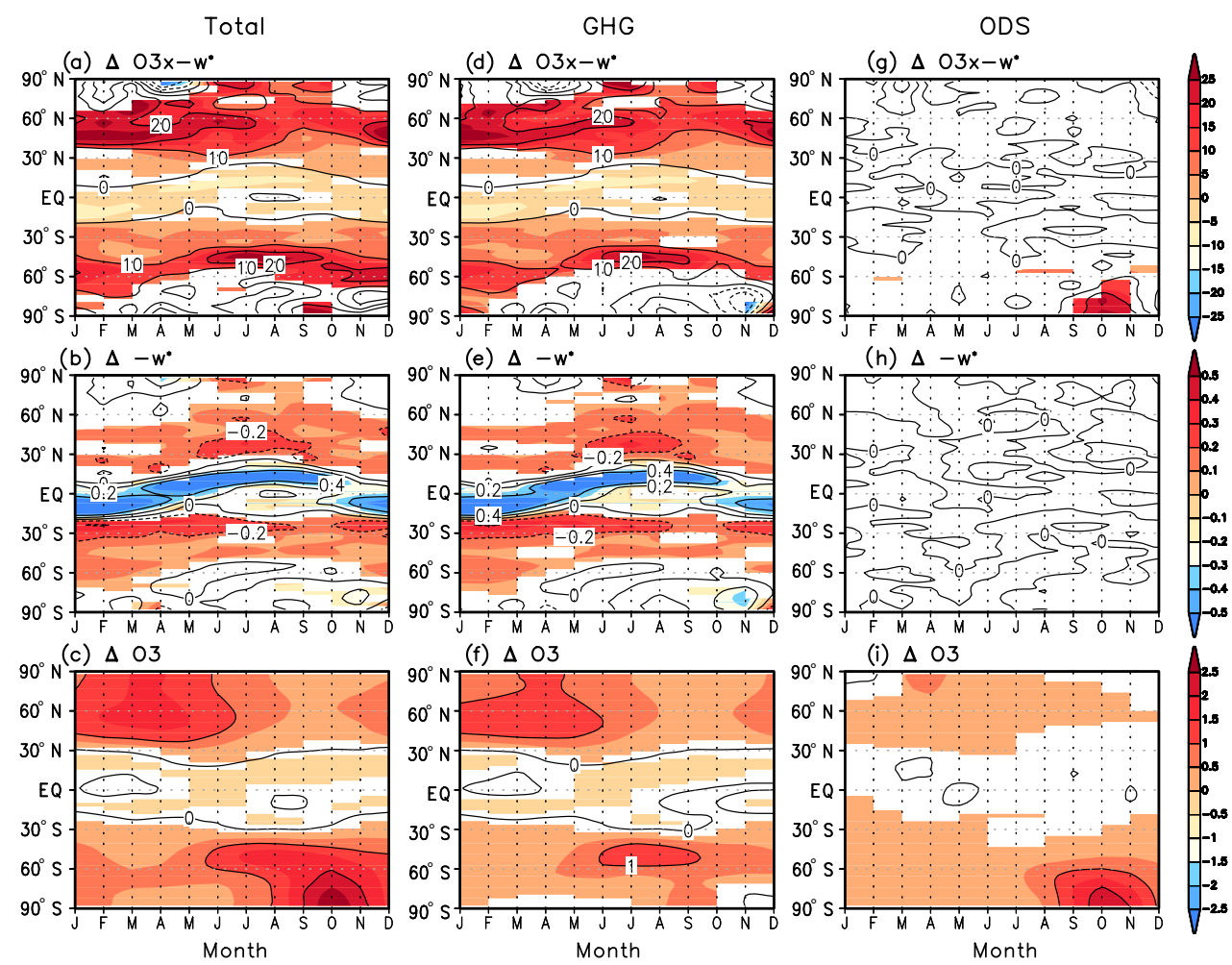

Figure 6. Annual cycle of the zonal mean change at $91 \mathrm{hPa}$ in the time-slice simulations due to all forcings between 2000 and 2100 $(\mathbf{a}-\mathbf{c})$, due to GHG increase $(\mathbf{d}-\mathbf{f})$, and due to ODS decrease $(\mathbf{g}-\mathbf{i})$. $(\mathbf{a}, \mathbf{d}, \mathbf{g})$ Changes in the product of ozone concentration and $-\bar{w}^{*}$ $\left[10^{6} \mathrm{~g} \mathrm{~cm}^{-2}\right.$ month $\left.^{-1}\right]$, which equals $F_{\text {in }}$ when integrated over all latitudes. (b, e, h) Changes in $-\bar{w}^{*}\left[\mathrm{~mm} \mathrm{~s}^{-1}\right]$. (c, f, i) Changes in the ozone concentration [molecules $\mathrm{cm}^{-2}$ ]. Significant changes at the $95 \%$ confidence level are colored.

19 Tg month $^{-1}(68 \%)$ in the SH. The GHG (Fig. 5d-f) and ODS (Fig. 5g-i) induced changes clearly indicate the dominant role of rising GHG concentrations for the future OMF change in the $\mathrm{NH}$. In the $\mathrm{NH}$, the GHG-related OMF increase is maximal in June and July, slightly shifting the peak in the annual cycle to later in summer which is consistent with the findings by Hegglin and Shepherd (2009). The ODS decrease, however, leads only to small positive and (not significant) negative changes in the $\mathrm{NH}$. In the $\mathrm{SH}$, the GHGinduced increase dominates the OMF change in winter and spring, while the ODS-related increase of the OMF contributes nearly equally to the total change in the SH summer. A significant reduction of OMF is found from August to October in the SH due to the ODS change. This causes a shift of the SH maximum ozone flux from October to December/January and is in contrast to the results by Hegglin and Shepherd (2009) who found the maximum SH OMF in the future (2090-2100) to occur in August. Overall we find that the GHG-induced changes will determine the positive trend of the OMF in the NH, while in the SH both ODS and GHG changes affect the trend and the seasonality of the future OMF into the troposphere.

To identify the processes behind the ODS- and GHGinduced changes, we analyze the changes of the two OMF components, i.e., $F_{\text {in }}$ and the seasonal breathing term. We find that the integrated $F_{\text {in }}$ will increase in the future throughout the year in both hemispheres and for both external forcings (not shown). To give a more detailed picture Fig. 6 shows (in the top row) the latitudinal distribution of the product of ozone concentration and $-\bar{w}^{*}$ at $91 \mathrm{hPa}$, which equals $F_{\text {in }}$, when integrated over all latitudes. The two components of $F_{\mathrm{in}},-\bar{w}^{*}$ and the ozone concentration, are shown separately in the middle and bottom rows of Fig. 6, respectively. The increase of $F_{\text {in }}\left(\right.$ or $\left.\mathrm{O}_{3} x-\bar{w}^{*}\right)$ due to the GHG effect (Fig. 6d) is caused by an increase in the downwelling (i.e., $-\bar{w}^{*}$, positive for downwelling, Fig. 6e) of the BDC in the winter season with climate change (e.g., Sudo et al., 2003; Butchart et al., 2010; Oberländer et al., 2013) in combination with an ozone increase resulting from modified chemical production and loss rates in the stratosphere and enhanced meridional transport (Fig. 6f). In contrast, with ODS decrease no significant changes in the downwelling occur (Fig. 6h). The small increase in $F_{\text {in }}$ (Fig. 6g) is therefore attributed to stratospheric ozone recovery from ODS, in particular in Antarctic spring (Fig. 6i). Figure 6 also indicates that the maximum change in OMF into the troposphere occurs at midlatitudes for the GHG increase and at high latitudes for the ODS reduction. This can be relevant for the mixing and 

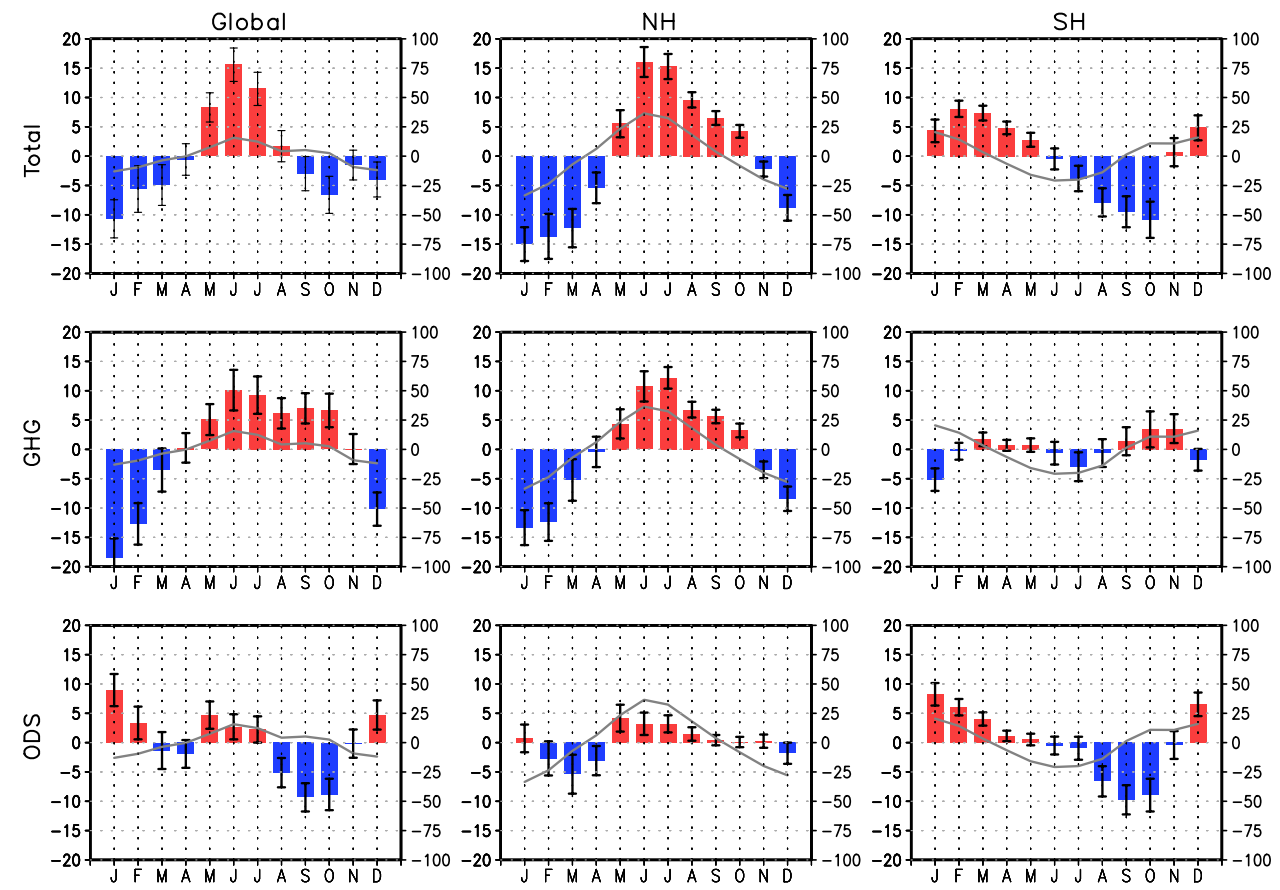

Figure 7. Same as Fig. 5 but for the change in seasonal breathing $(-\mathrm{d} M / \mathrm{d} t)\left[\operatorname{Tg}_{\text {month }}{ }^{-1}\right]$. The absolute value for $-\mathrm{d} M / \mathrm{d} t$ of the reference simulation REF2000 is shown as a grey line with the corresponding $y$ axis on the right.

distribution of stratospheric ozone in the troposphere (see below).

Thus, given the positive changes in $F_{\text {in }}$, the significant negative change in the OMF identified in September and October for the ODS decrease, must be attributed to changes in $-\mathrm{d} M / \mathrm{d} t$ (i.e., the monthly change in the ozone mass contained in the LMS, also referred to as seasonal breathing, Fig. 7). While the total mass in the LMS is decreasing with rising GHG concentrations in the sensitivity simulations (possibly due to the tropopause lifting effect of rising GHGs), it slightly increases with ODS change only (not shown). The mass of ozone $(M)$, however, is increasing globally due to both, GHGs and ODS. Thus, for the GHG effect, the future increase of ozone in the LMS outweighs the reduction in total LMS mass. If this future increase of $M$ in the LMS varies monthly, a future change (positive or negative) in $-\mathrm{d} M / \mathrm{d} t$ will result. This change in $-\mathrm{d} M / \mathrm{d} t$ (i.e., the seasonal breathing) is shown in Fig. 7. In the SH spring, when the ozone mass increase is steadily amplified between August and November due to the decline of ODS, a considerable change in $-\mathrm{d} M / \mathrm{d} t$ results. This leads to the shift of the seasonality of the OMF and therefore to negative changes in the SH spring.

As mentioned above, the timing of the strongest input of stratospheric ozone into the troposphere is relevant in that the efficiency of mixing down to lower altitudes or to the surface depends on the chemical lifetime of ozone which varies with season. A shift of the spring maximum in the SH to sum- mer (December/January) for instance may result in different mean abundances of $\mathrm{O}_{3} \mathrm{~s}$ in the troposphere. Furthermore, the chemical loss of ozone will increase in a warmer troposphere, affecting the lifetime of ozone and thus the distribution of stratospheric ozone in the troposphere.

The future changes in the distribution of $\mathrm{O}_{3}$ s mixing ratios are shown in Fig. 8 for June. $\mathrm{O}_{3} \mathrm{~s}$ is projected to increase throughout the extratropical troposphere. The largest changes will occur in the subtropics in the upper and middle troposphere, the regions where cross-tropopause transport along isentropic surfaces is possible and ozone is efficiently transported into the troposphere through tropopause folds. This pattern is caused by the rising GHG concentrations (Fig. 8b). Near the surface however, the $\mathrm{O}_{3}$ s mixing ratios will decrease with GHG change at summer NH mid-latitudes, either induced by an increased chemical $\mathrm{O}_{3}$ s loss or dry deposition. The total positive change near the surface results from the $\mathrm{O}_{3} \mathrm{~s}$ increase due to ODS change (Fig. 8c). In the SH, the abundance of stratospheric ozone increases throughout the troposphere down to the surface. Here, more $\mathrm{O}_{3} \mathrm{~s}$ is present at lower altitudes than in the $\mathrm{NH}$, which may be related to the longer chemical lifetime of ozone in winter. This is also obvious from the ODS-induced changes, albeit with very small signals.

The annual mean column-integrated values of $\mathrm{O}_{3} \mathrm{~s}$ and ozone in the troposphere and their respective changes are listed in Table 3 . The $\mathrm{O}_{3}$ s column increases globally by $42 \%$ between the years 2000 and 2100, with a larger change oc- 

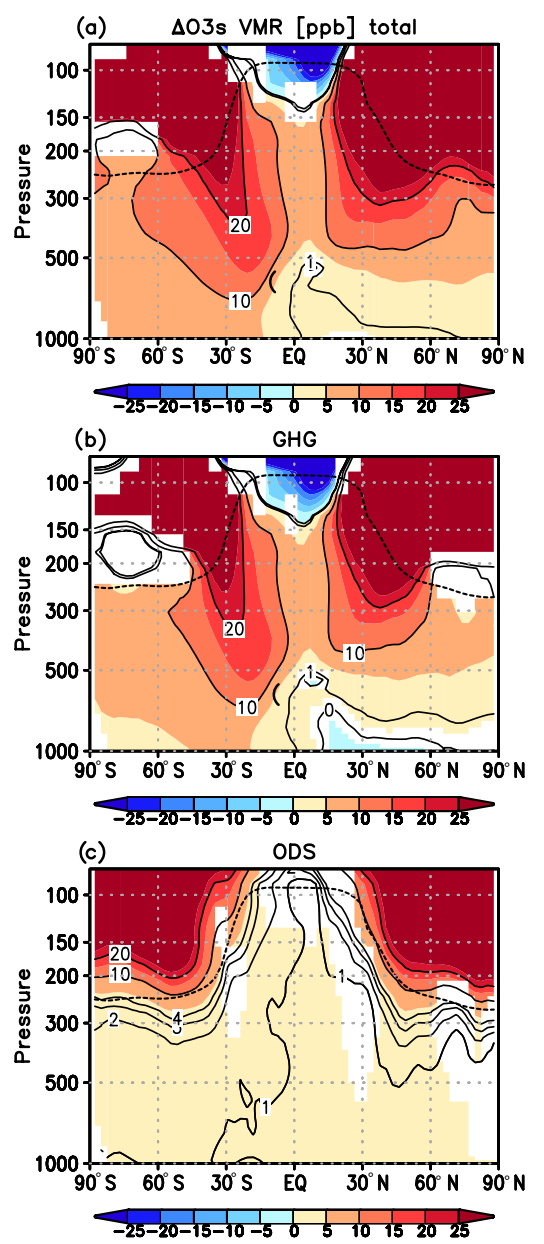

Figure 8. Changes in the volume mixing ratios [ppbv] of the diagnostic tracer $\mathrm{O}_{3} \mathrm{~s}$ for (a) the changes between 2000 and 2100 due to all forcings, (b) the changes between 2000 and 2100 due to increasing GHG concentrations and (c) the changes between 2000 and 2100 due to declining ODS levels for June (when the ozone mass flux is maximum in the $\mathrm{NH}$ and minimum in the $\mathrm{SH}$; see Fig. 2a). Significant changes at the $95 \%$ confidence level are colored. The black dotted line represents the mean tropopause position in the REF2000 simulation. For the small ODS-induced changes (c) additional contour lines (2, 3, and 4 ppbv) are shown.

curring in the SH than in the NH. Consistent with the results above, the change due to GHG is larger than due to ODS. As expected the ODS decrease has a larger effect on the $\mathrm{SH}$ $(+6 \%)$ than on the $\mathrm{NH}(+2 \%)$. By splitting the increase in the total burden of tropospheric ozone $\left(=\mathrm{O}_{3} \mathrm{~s}+\mathrm{O}_{3} \mathrm{t}\right)$ between 2000 and 2100 into the single components $\mathrm{O}_{3} \mathrm{~s}$ and $\mathrm{O}_{3} \mathrm{t}$ (derived from Table 3), we find that the main contribution to the change is from $\mathrm{O}_{3} \mathrm{~s}(19 \%)$, whereas ozone produced in the troposphere $\left(\mathrm{O}_{3} \mathrm{t}\right.$, calculated as residual $)$ causes an increase of $12 \%$ summing up to a total increase of $31 \%$ of tropospheric ozone. The larger increase in the ozone mass flux (Table 2) compared to the increase of $\mathrm{O}_{3}$ s columns in the troposphere indicates changing chemical conditions in the tro- posphere due to climate change. This means that the larger amount of stratospheric ozone entering the troposphere does not accumulate to the equivalent larger abundance of $\mathrm{O}_{3} \mathrm{~s}$ in the troposphere.

Next we investigate the extent to which the future change in $\mathrm{O}_{3} \mathrm{~s}$ (Fig. 9b-h) contributes to the ozone change (Fig. 9ag) in the troposphere. The relative contribution is shown in Fig. $9 \mathrm{c}-\mathrm{i}$ as annual cycle of the tropospheric columns for the change between 2000 and 2100 due to all forcings (c), the respective change due to GHGs (f), and the respective change due to ODS (i). We find that at SH middle and high latitudes more than $80 \%$ of the increase in the tropospheric ozone column is caused by ozone originating from the stratosphere from April through October. A similarly strong contribution to the overall change of more than $80 \%$ occurs in the NH extratropics, however it is confined to the spring season (March, April, and May). For the rest of the year, ozone originating from the stratosphere causes more than $50 \%$ of the total change in both hemispheres. In contrast, in the tropics only 20 to $50 \%$ of the ozone change are attributable to changes in ozone from the stratosphere throughout the year.

In addition, our simulations illustrate that the future enhancement of stratospheric ozone import into the troposphere and the resulting tropospheric ozone change will be dominated by the GHG effect. If only the concentrations of ODS would decline between the years 2000 and 2100, a minor increase in tropospheric ozone burden in the (mainly $\mathrm{SH}$ ) extratropics would form (Fig. 9g), which is almost completely attributable to increased stratospheric ozone entering into the troposphere (Fig. 9h and i). In the GHG only simulation up to $80 \%$ of the tropospheric ozone trends in the $\mathrm{SH}$ winter and $70 \%$ in the $\mathrm{NH}$ spring can be explained by increased abundances of $\mathrm{O}_{3} \mathrm{~s}$ (Fig. 9f). These numbers also indicate the strong increase of tropospheric photochemical ozone production in the future due to the doubling of methane emissions under the RCP8.5 scenario (e.g., Young et al., 2013; Meul et al., 2016). In the NH summer, about $50 \%$ of the change is due to stratospheric ozone, while in the tropics and the SH summer months, the contribution is less than $40 \%$. In summary, Fig. 9 shows that, as expected, the input of stratospheric ozone is the driver of ozone changes in the troposphere, if only ODS levels are reduced. There is no considerable change in tropospheric chemistry due to larger ODS abundances. In contrast, for the GHG increase we find that other processes, such as tropospheric chemistry, modulate the tropospheric ozone abundance in addition to the increased influx of stratospheric ozone.

Finally, we compare the tropospheric $\mathrm{O}_{3}$ s columns derived from the time-slice simulations under the RCP8.5 scenario with the transient simulation using the RCP6.0 scenario. Figure 10a shows the evolution of annual mean tropospheric ozone (solid) and $\mathrm{O}_{3} \mathrm{~s}$ (dashed) columns for the $\mathrm{NH}$ and the SH. Tropospheric ozone increases in the RCP6.0 simulation from 1960 to the middle of the 21 st century and slightly declines afterwards in the $\mathrm{NH}$, while it stays nearly constant 
Total
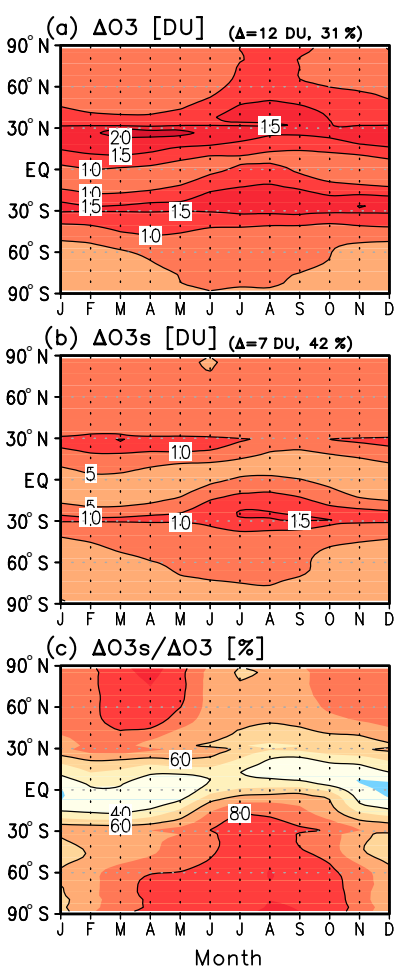

GHG

(d) $\triangle \mathrm{O} 3[\mathrm{DU}]$
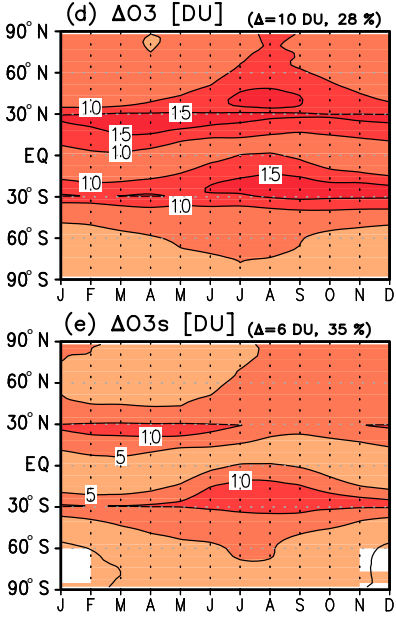

(f) $\Delta 03 \mathrm{~s} / \Delta \mathrm{O} 3[\%]$

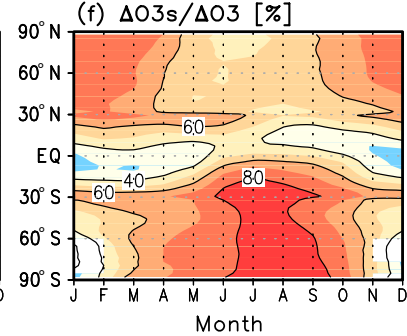

ODS

(g) $\Delta \mathrm{O} 3[\mathrm{DU}] \quad(\Delta=1 \mathrm{DU}, 2 \%)$

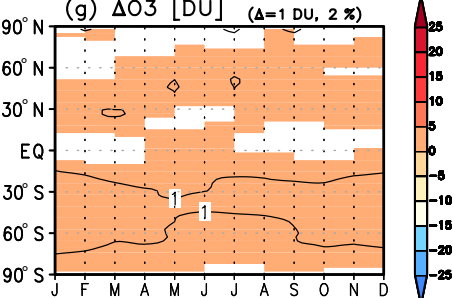

(h) $\Delta$ O3s [DU] ( $\Delta=1$ DU, $4 \%)$

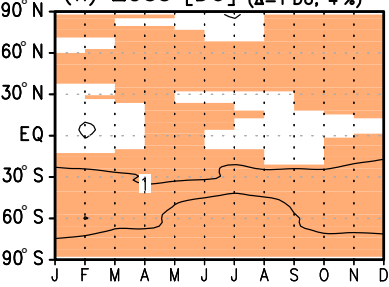

(i) $\Delta 03 \mathrm{~s} / \Delta 03[\%]$

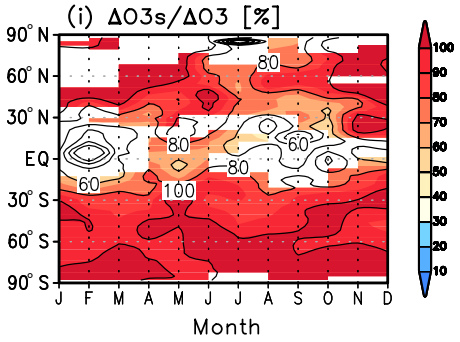

Figure 9. Same as Fig. 6, but for the change in the tropospheric columns of $\mathrm{O}_{3}$ [DU] (a, d, $\left.\mathbf{g}\right)$, the tropospheric columns of $\mathrm{O}_{3} \mathrm{~s}$ [DU] (b, e, h), and the contribution of the $\mathrm{O}_{3}$ s changes to the $\mathrm{O}_{3}$ changes between 2000 and 2100 [\%] (c, f, i). The small numbers on top of the figures are the respective annual mean and global mean changes in Dobson units and percent. Shading in the bottom row indicates the regions where both $\mathrm{O}_{3}$ s and $\mathrm{O}_{3}$ changes are significant at the $95 \%$ confidence level.

Table 3. Overview of the annual mean $\mathrm{O}_{3}$ and $\mathrm{O}_{3}$ s burden $[\mathrm{Tg}]$ in the troposphere with the corresponding standard deviations in the EMAC time-slice simulations. Bold numbers indicate the change relative to the REF2000 simulation. All changes are significant at the $95 \%$ confidence level.

\begin{tabular}{|c|c|c|c|c|c|c|}
\hline & \multicolumn{3}{|c|}{ Tropospheric $\mathrm{O}_{3}$ column $[\mathrm{Tg}]$} & \multicolumn{3}{|c|}{ Tropospheric $\mathrm{O}_{3}$ s column $[\mathrm{Tg}]$} \\
\hline & Global mean & $\mathrm{NH}$ & $\mathrm{SH}$ & Global mean & NH & SH \\
\hline REF2000 & $401 \pm 2$ & $222 \pm 2$ & $179 \pm 1$ & $182 \pm 3$ & $96 \pm 2$ & $86 \pm 2$ \\
\hline REF2100 & $\begin{array}{r}527 \pm 3 \\
+\mathbf{3 1} \%\end{array}$ & $\begin{array}{r}290 \pm 2 \\
+\mathbf{3 1} \%\end{array}$ & $\begin{array}{r}237 \pm 2 \\
+\mathbf{3 2} \%\end{array}$ & $\begin{array}{r}258 \pm 4 \\
+42 \%\end{array}$ & $\begin{array}{r}134 \pm 2 \\
+\mathbf{4 0} \%\end{array}$ & $\begin{array}{l}123 \pm 2 \\
+\mathbf{4 3} \%\end{array}$ \\
\hline GHG2100 & $\begin{array}{r}513 \pm 3 \\
+\mathbf{2 8} \%\end{array}$ & $\begin{array}{r}282 \pm 2 \\
+27 \%\end{array}$ & $\begin{array}{r}231 \pm 2 \\
+\mathbf{2 9} \%\end{array}$ & $\begin{array}{r}246 \pm 3 \\
+35 \%\end{array}$ & $\begin{array}{r}128 \pm 2 \\
+33 \%\end{array}$ & $\begin{array}{l}118 \pm 2 \\
+37 \%\end{array}$ \\
\hline ODS2100 & $\begin{array}{r}409 \pm 2 \\
+2 \%\end{array}$ & $\begin{array}{r}225 \pm 2 \\
+1 \%\end{array}$ & $\begin{array}{r}184 \pm 1 \\
+3 \%\end{array}$ & $\begin{array}{r}189 \pm 2 \\
+4 \%\end{array}$ & $\begin{array}{r}98 \pm 1 \\
+2 \%\end{array}$ & $\begin{array}{r}91 \pm 1 \\
+6 \%\end{array}$ \\
\hline
\end{tabular}

in the SH. There is very good agreement of the tropospheric ozone column between the transient and time-slice simulations for the year 2000, when both simulations use observed GHG concentrations. Regarding the temporal evolution of $\mathrm{O}_{3} \mathrm{~s}$, we find a positive trend in both hemispheres and only a slight decrease in the NH at the end of the 21 st century. In the past, an effect of the ODS driven stratospheric ozone loss is overlaid by the GHG related increase in both hemispheres.
However, a slightly smaller rise of $\mathrm{O}_{3} \mathrm{~s}$ in the $\mathrm{SH}$ might be an indication.

The RCP8.5 scenario (circles) leads to higher values of tropospheric ozone in 2100 which is related to two effects: a larger import of stratospheric ozone and a larger chemical ozone production in the troposphere due to strongly enhanced methane concentrations in the second half of the $21 \mathrm{st}$ century (see Meinshausen et al., 2011). 

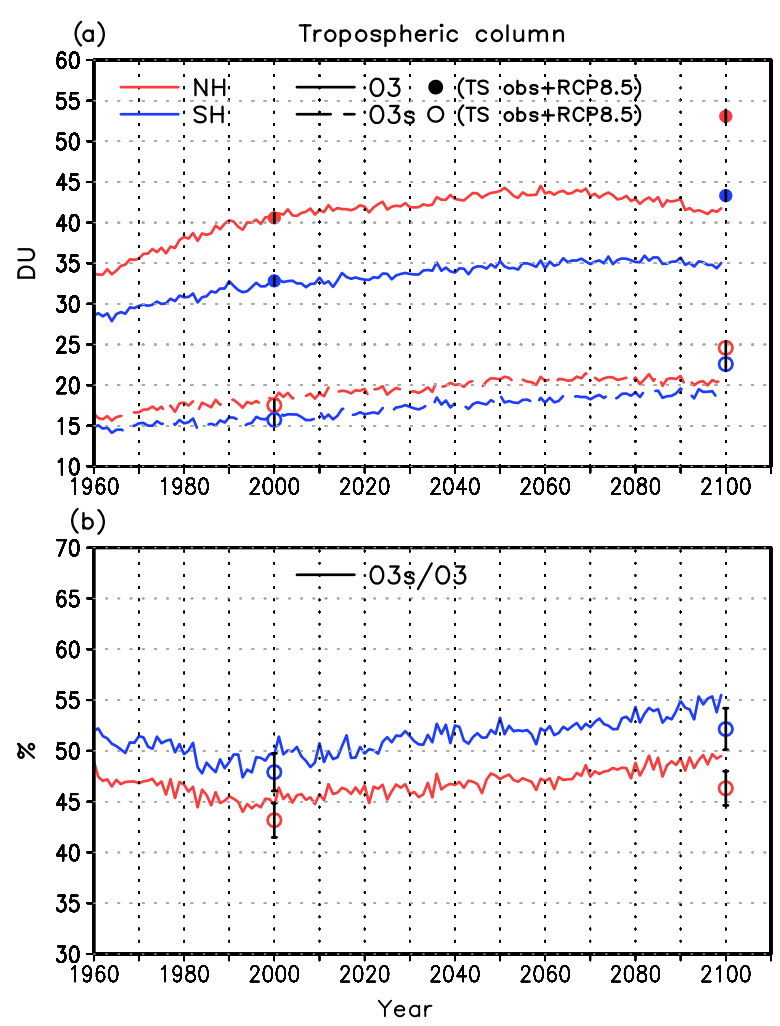

Figure 10. (a) Temporal evolution of the annual mean tropospheric column in ozone (solid) and $\mathrm{O}_{3}$ s (dashed) [DU] averaged for the Northern Hemisphere (red) and the Southern Hemisphere (blue) in the transient RCP6.0 simulation and the corresponding values of the reference time-slice simulations for the year 2000 and 2100 (ozone: closed circle; $\mathrm{O}_{3} \mathrm{~s}$ : open circle). (b) Same as (a) but for the ratio between $\mathrm{O}_{3}$ s and $\mathrm{O}_{3}[\%]$. The black bars denote the $\pm 2 \sigma$ range for the time-slice simulations. Note that the interannual variability in ozone and $\mathrm{O}_{3} \mathrm{~s}$ is small in the time-slice simulations and the error bars are very short.

The ratio between $\mathrm{O}_{3}$ s and tropospheric ozone (Fig. 10b) gives an indication of whether or not the role of stratospheric ozone in the troposphere will change in the future. In the past period of the transient simulation (i.e., RCP6.0 scenario), the relative contribution of $\mathrm{O}_{3}$ s decreases from $48 \%$ (1960s) to $44 \%$ (1990s) in the $\mathrm{NH}$ and from 52 to $48 \%$ in the SH. This is caused by an increase of ozone produced in the troposphere, which is stronger than the increase of $\mathrm{O}_{3} \mathrm{~s}$ (Fig. 10a). In the future, however, the relative importance of ozone from the stratosphere increases, reaching $49 \%$ in the $\mathrm{NH}$ and $55 \%$ in the $\mathrm{SH}$ around the year 2100. Thus, in the RCP6.0 scenario (more than) half of the ozone in the troposphere will originate from the stratosphere in the (SH) NH by the end of the 21 st century.

The comparison with the time-slice simulation (RCP8.5 GHG scenario) shows that the contribution of $\mathrm{O}_{3} \mathrm{~s}$ to $\mathrm{O}_{3}$ in the troposphere is lower in the year 2000 than in the transient simulation. This is probably caused by the differ- ent data sets used for the SST/SIC fields in the time-slice and transient simulation (see Table 1) leading to different tropopause heights and therefore to different tropospheric columns. However, the larger contribution of $\mathrm{O}_{3}$ s to ozone in the SH (48\%) compared to the $\mathrm{NH}(43 \%)$ is confirmed. In $2100,46 \%$ (52\%) of the annual mean tropospheric ozone column in the $\mathrm{NH}(\mathrm{SH})$ will consist of ozone originating from the stratosphere.

In summary, in a future RCP6.0 scenario, the relative importance of ozone from the stratosphere in the troposphere will increase by $5 \%$ in the $\mathrm{NH}$ and $7 \%$ in the $\mathrm{SH}$ around the year 2100 compared to 1990 . In the RCP8.5 scenario, the increase will be slightly smaller (3\% in the $\mathrm{NH}$ and $4 \%$ in the SH in 2100 compared to 2000) despite the larger increase in OMF shown in Fig. 2. Here, the different evolution of tropospheric ozone production in the two GHG scenarios plays a crucial role.

\section{Summary}

In this study we have analyzed the future changes in stratosphere-to-troposphere transport of ozone in time-slice and transient simulations with the CCM EMAC to address the questions raised in the introduction:

1. How will the stratosphere-to-troposphere OMF change in the future?

2. What are the major drivers of future changes in stratosphere-to-troposphere OMF?

3. Will the seasonality of the STE change in future?

4. How will GHG emission scenarios affect the OMF into the troposphere?

5. How is the ratio of stratospheric ozone in the troposphere changed in the future?

In agreement with other studies (e.g., Sudo et al., 2003; Collins et al., 2003; Hegglin and Shepherd, 2009; Banerjee et al., 2016), we find that the influx of stratospheric ozone into the troposphere will increase in the future. Between 2000 and 2100 the EMAC time-slice simulations project an increase of the annual global mean OMF by $53 \%$ under the RCP 8.5 scenario. Increasing GHG concentrations were identified as the main driver of the rising OMF into the troposphere as they strengthen the BDC and increase the net ozone production in the stratosphere. The annual global OMF is increased by $46 \%$ due to rising GHG concentrations compared to an increase of $7 \%$ due to the ODS decline and the associated ozone recovery. The GHG effect leads to a larger intensification of STE in the NH (51\%) than in the SH (40\%), whereas the ODS effect is most prominent in the SH (9\%) compared to $4 \%$ in the $\mathrm{NH}$.

Regarding the seasonal changes of the OMF, we showed the dominant role of GHG changes for the $\mathrm{NH}$ whereas in the 
SH, both ODS and GHG changes affect the seasonality of the OMF increase: the GHG increase is the main driver of the increase in winter and spring, but in summer ODS-induced changes also contribute to the OMF increase. Furthermore, the ODS decrease and the concomitant ozone increase in the lower stratosphere during the $\mathrm{SH}$ spring cause a large change in the seasonal breathing term in the SH from August to October, which results in a shift of the maximum ozone flux to late spring/early summer. The GHG effect leads to a dampened amplitude of the seasonal cycle in the SH and an intensified amplitude in the NH. This can have an impact on the distribution of stratospheric ozone in the troposphere: in the SH more ozone is transported into the troposphere in winter, when the chemical lifetimes are relatively long, whereas in the $\mathrm{NH}$ the largest increase is found in summer. This may explain the larger increase of $\mathrm{O}_{3}$ s columns in the $\mathrm{SH}$ compared to the NH despite the smaller increase in OMF (see Tables 2 and 3).

The future spatial distribution of the tropospheric $\mathrm{O}_{3}$ s column in the troposphere is determined by the change pattern due to GHG increases. Here, the largest increase of $\mathrm{O}_{3}$ s mixing ratios occurs in the subtropical upper troposphere, where stratospheric ozone is transported into the troposphere via tropopause folds and then further down to lower levels in the large-scale sinking of the Hadley cell (Roelofs and Lelieveld, 1997). ODS-related changes in the tropospheric $\mathrm{O}_{3}$ s column are smaller. They show no comparable signal in the subtropical region, but a more homogeneous distribution. In the ODS simulation, the main increase of stratospheric ozone input occurs via the downward branch of the BDC in middle and higher latitudes, where the chemical ozone loss of tropospheric ozone is smaller than in the subtropics and hence mixing towards the surface is more efficient.

In the $\mathrm{SH}$ winter months, the ozone change due to increased stratospheric ozone influx explains up to $80 \%$ of the overall tropospheric ozone increase under the RCP8.5 scenario by the end of the century. In the rest of the year, the stratospheric ozone changes cover more than $50 \%$ of the ozone changes in the SH troposphere. In contrast, increased stratospheric ozone only explains about $70 \%$ of the ozone changes in the $\mathrm{NH}$ spring indicating the strong increase of tropospheric photochemical ozone production in the future due to the doubling of methane emissions under the RCP8.5 scenario.

The comparison with the transient EMAC simulation under the RCP6.0 scenario shows a smaller future increase in annual global OMF into the troposphere ( $4.2 \%$ per decade) than under the RCP8.5 scenario (5.3\% per decade). In the transient RCP6.0 simulation the positive trend between 2000 and 2100 is larger in the $\mathrm{SH}$ than in the $\mathrm{NH}$, which is not found in the RCP8.5 time slices. The stronger increase in the OMF under the RCP8.5 scenario is connected with a larger $\mathrm{O}_{3}$ s column, but the relative contribution of $\mathrm{O}_{3} \mathrm{~s}$ to ozone in the troposphere rises similarly in both scenarios. This is caused by the different evolution of the ozone pro- duced in the troposphere in the RCP6.0 and RCP8.5 scenario due to the deviating emission scenarios for the ozone precursor species. In the past, the input of stratospheric ozone has decreased slightly (between 1960 and 1999), especially in the $\mathrm{SH}(-1.4 \%$ per decade) due to the formation of the ozone hole. However, the $\mathrm{O}_{3}$ s column in the troposphere integrated over the $\mathrm{NH}$ and the $\mathrm{SH}$ shows a small positive trend. This may be related to the seasonal timing of the changes, as ozone loss in the SH stratosphere has the largest effect on the OMF in spring and early summer when the tropospheric ozone loss rates are higher than in winter and mixing is less efficient.

In summary, this study shows that GHG and ODS changes have different effects on the future OMF, its seasonality, and the resulting abundances of stratospheric ozone in the troposphere. Moreover, it shows that both forcings are projected to cause an increased amount of stratospheric ozone in the troposphere, which will not only contribute to the radiative forcing and global warming but will also affect the air quality at the surface. Further studies are needed to investigate and separate the effect of non-methane precursors on the OMF, their interactions with the increasing GHGs, and the resulting distribution of $\mathrm{O}_{3} \mathrm{~s}$ in the troposphere.

Code availability. The Modular Earth Submodel System (MESSy), including the EMAC model, is continuously further developed and applied by a consortium of institutions. The usage of MESSy and access to the source code is licensed to all affiliates of institutions, which are members of the MESSy consortium. Institutions can become a member of the MESSy consortium by signing the MESSy Memorandum of Understanding. More information can be found on the MESSy Consortium website (http://www.messy-interface.org, last access: 31 May 2018).

Data availability. The data from the ESCiMo simulation RC2-base-05 are available on the website of the ChemistryClimate Model Initiative (http://catalogue.ceda.ac.uk/uuid/ 9cc6b94df0f4469d8066d69b5df879d5, last access: 31 May 2018). Data from the EMAC time-slice simulations performed for this paper are available at the Freie Universität Berlin on the SHARP data archive under ACPD_ozone_transport_Meul_et_al_2018.tar and can be obtained by contacting Ulrike.Langematz@met.fu-berlin.de.

Author contributions. SM performed and analyzed the time-slice simulations and wrote the manuscript. UL initialized the study and contributed considerably to the manuscript and the discussion. PK contributed to the analysis of the model data. SOH performed the time-slice simulations and contributed to the discussion of the results. PJ led the ESCiMo project, coordinated the preparation of the EMAC simulation setups and conducted the model simulations (here RC2-base-05). Moreover, he contributed to the EMAC model development, including the $\mathrm{O}_{3}$ s diagnostics applied in this paper. 
Competing interests. The authors declare that they have no conflict of interest.

Special issue statement. This article is part of the special issue "The Modular Earth Submodel System (MESSy) (ACP/GMD interjournal SI)". It is not associated with a conference.

Acknowledgements. This work has been funded by the Deutsche Forschungsgemeinschaft (DFG) within the DFG Research Unit FOR 1095 "Stratospheric Change and its Role for Climate Prediction" (SHARP) under grants LA 1025/13-2 and LA 1025/14-2. The authors are grateful to the North-German Supercomputing Alliance (HLRN) for providing computer resources and support. The EMAC model simulation RC2-base-05 was performed at the German Climate Computing Centre (DKRZ) through support from the Bundesministerium für Bildung und Forschung (BMBF). DKRZ and its scientific steering committee are gratefully acknowledged for providing the HPC and data archiving resources for the projects 853 (ESCiMo - Earth System Chemistry integrated Modelling). The authors wish to thank two anonymous referees for their helpful comments and Janice Scheffler for supporting the revision.

Edited by: Jens-Uwe Grooß

Reviewed by: two anonymous referees

\section{References}

Andrews, T., Gregory, J. M., Webb, M. J., and Taylor, K. E.: Forcing, feedbacks and climate sensitivity in CMIP5 coupled atmosphere-ocean climate models, Geophys. Res. Lett., 39, L09712, https://doi.org/10.1029/2012GL051607, 2012.

Akritidis, D., Pozzer, A., Zanis, P., Tyrlis, E., Škerlak, B., Sprenger, M., and Lelieveld, J.: On the role of tropopause folds in summertime tropospheric ozone over the eastern Mediterranean and the Middle East, Atmos. Chem. Phys., 16, 14025-14039, https://doi.org/10.5194/acp-16-14025-2016, 2016.

Appenzeller, C., Holton, J. R., and Rosenlof, K. H.: Seasonal variation of mass transport across the tropopause, J. Geophys. Res., 101, 15071-15078, https://doi.org/10.1029/96JD00821, 1996.

Banerjee, A., Maycock, A. C., Archibald, A. T., Abraham, N. L., Telford, P., Braesicke, P., and Pyle, J. A.: Drivers of changes in stratospheric and tropospheric ozone between year 2000 and 2100, Atmos. Chem. Phys., 16, 2727-2746, https://doi.org/10.5194/acp-16-2727-2016, 2016.

Barré, J., El Amraoui, L., Ricaud, P., Lahoz, W. A., Attié, J.L., Peuch, V.-H., Josse, B., and Marécal, V.: Diagnosing the transition layer at extratropical latitudes using MLS $\mathrm{O}_{3}$ and MOPITT CO analyses, Atmos. Chem. Phys., 13, 7225-7240, https://doi.org/10.5194/acp-13-7225-2013, 2013.

Butchart, N., Cionni, I., Eyring, V., Shepherd, T. G., Waugh, D. W., Akiyoshi, H., Austin, J., Brühl, C., Chipperfield, M. P., Cordero, E., Dameris, M., Deckert, R., Dhomse, S., Frith, S. M., Garcia, R. R., Gettelman, A., Giorgetta, M. A., Kinnison, D. E., Li, F., Mancini, E., McLandress, C., Pawson, S., Pitari, G., Plummer, D. A., Rozanov, E., Sassi, F., Scinocca, J. F., Shibata, K., Steil, B., and Tian, W.: Chemistry-Climate Model Simulations of Twenty-
First Century Stratospheric Climate and Circulation Changes, J. Climate, 23, 5349-5374, 2010.

Butchart, N. and Scaife, A.: Removal of chlorofluorocarbons by increased mass exchange between the stratosphere and troposphere in a changing climate, Nature, 410, 799-801, https://doi.org/10.1038/35071047, 2010.

Collins, W. J., Derwent, R. G., Garnier, B., Johnson, C. E., Sanderson, M. G., and Stevenson, D. S.: Effect of stratosphere-troposphere exchange on the future tropospheric ozone trend, J. Geophys. Res., 108, 8528, https://doi.org/10.1029/2002JD002617, 2003.

Collins, W. J., Bellouin, N., Doutriaux-Boucher, M., Gedney, N., Halloran, P., Hinton, T., Hughes, J., Jones, C. D., Joshi, M., Liddicoat, S., Martin, G., O'Connor, F., Rae, J., Senior, C., Sitch, S., Totterdell, I., Wiltshire, A., and Woodward, S.: Development and evaluation of an Earth-System model - HadGEM2, Geosci. Model Dev., 4, 1051-1075, https://doi.org/10.5194/gmd-4-10512011, 2011.

Fischer, H., Wienhold, F. G., Hoor, P., Bujok, O., Schiller, C., Siegmund, P., Ambaum, M., Scheeren, H. A., and Lelieveld, J.: Tracer correlations in the northern high latitude lowermost stratosphere: Influence of cross-tropopause mass exchange, Geophys. Res. Lett., 27, 97-100, https://doi.org/10.1029/1999GL010879, 2000.

Giorgetta, M. A. and Bengtsson, L.: Potential role of the quasi-biennial oscillation in the stratosphere-troposphere exchange as found in water vapor in general circulation model experiments, J. Geophys. Res.-Atmos., 104, 6003-6019, https://doi.org/10.1029/1998JD200112, 1999.

Giorgetta, M. A., Jungclaus, J., Reick, C. H., Legutke, S., et al.: Climate and carbon cycle changes from 1850 to 2100 in MPI-ESM simulations for the Coupled Model Intercomparison Project phase 5, J. Adv. Model. Earth Syst., 5, 572-597, https://doi.org/10.1002/jame.20038, 2013.

Hegglin, M. I. and Shepherd, T. G.: $\mathrm{O}_{3}-\mathrm{N}_{2} \mathrm{O}$ correlations from the Atmospheric Chemistry Experiment: Revisiting a diagnostic of transport and chemistry in the stratosphere, J. Geophys. Res., 112, D19301, https://doi.org/10.1029/2006JD008281, 2007.

Hegglin, M. and Shepherd, T.: Large climate-induced changes in ultraviolet index and stratosphere-to-troposphere ozone flux, Nature Geosci., 2, 687-691, https://doi.org/10.1038/ngeo604, 2009.

Hegglin, M. I., Boone, C. D., Manney, G. L., and Walker, K. A.: A global view of the extratropical tropopause transition layer from Atmospheric Chemistry Experiment Fourier Transform Spectrometer $\mathrm{O}_{3}, \mathrm{H}_{2} \mathrm{O}$, and CO, J. Geophys. Res., 114, D00B11, https://doi.org/10.1029/2008JD009984, 2009.

Holton, J. R., Haynes, P. H., McIntyre, M. E., Douglass, A. R., Rood, R. B., and Pfister, L.: Stratosphere-troposphere exchange, Rev. Geophys., 33, 403-439, 1995.

Intergovernmental Panel on Climate Change: Climate change 2001: The scientific basis, Contribution of Working Group 1 to the Third Assessment Report, Cambridge, United Kingdom and New York, NY, USA, 2001.

Jöckel, P., Tost, H., Pozzer, A., Kunze, M., Kirner, O., Brenninkmeijer, C. A. M., Brinkop, S., Cai, D. S., Dyroff, C., Eckstein, J., Frank, F., Garny, H., Gottschaldt, K.-D., Graf, P., Grewe, V., Kerkweg, A., Kern, B., Matthes, S., Mertens, M., Meul, S., Neumaier, M., Nützel, M., Oberländer-Hayn, S., Ruhnke, R., Runde, T., Sander, R., Scharffe, D., and Zahn, A.: Earth System Chem- 
istry integrated Modelling (ESCiMo) with the Modular Earth Submodel System (MESSy) version 2.51, Geosci. Model Dev., 9, 1153-1200, https://doi.org/10.5194/gmd-9-1153-2016, 2016.

Johnson, C. E., Collins, W. J., Stevenson, D. S., and Derwent, R. G.: Relative roles of climate and emissions changes on future tropospheric oxidant concentrations, J. Geophys. Res.-Atmos., 104, 18631-18645, https://doi.org/10.1029/1999JD900204, 1999.

Jonsson, A. I., de Grandpré, J., Fomichev, V. I., McConnell, J. C., and Beagley, S. R.: Doubled $\mathrm{CO}_{2}$-induced cooling in the middle atmosphere: Photochemical analysis of the ozone radiative feedback, J. Geophys. Res., 109, D24103, https://doi.org/10.1029/2004JD005093, 2004.

Martin, G. M., Bellouin, N., Collins, W. J., Culverwell, I. D., Halloran, P. R., Hardiman, S. C., Hinton, T. J., Jones, C. D., McDonald, R. E., McLaren, A. J., O'Connor, F. M., Roberts, M. J., Rodriguez, J. M., Woodward, S., Best, M. J., Brooks, M. E., Brown, A. R., Butchart, N., Dearden, C., Derbyshire, S. H., Dharssi, I., Doutriaux-Boucher, M., Edwards, J. M., Falloon, P. D., Gedney, N., Gray, L. J., Hewitt, H. T., Hobson, M., Huddleston, M. R., Hughes, J., Ineson, S., Ingram, W. J., James, P. M., Johns, T. C., Johnson, C. E., Jones, A., Jones, C. P., Joshi, M. M., Keen, A. B., Liddicoat, S., Lock, A. P., Maidens, A. V., Manners, J. C., Milton, S. F., Rae, J. G. L., Ridley, J. K., Sellar, A., Senior, C. A., Totterdell, I. J., Verhoef, A., Vidale, P. L., and Wiltshire, A.: The HadGEM2 family of Met Office Unified Model climate configurations, Geosci. Model Dev., 4, 723-757, https://doi.org/10.5194/gmd-4-723-2011, 2011.

Meinshausen, M., Smith, S. J., Calvin, K. V., Daniel, J. S., Kainuma, M. L. T., Lamarque, J.-F., Matsumoto, K., Montzka, S. A., Raper, S. C. B., Riahi, K., Thomson, A. M.,Velders, G. J. M., and van Vuuren, D.: The RCP Greenhouse Gas Concentrations and their Extension from 1765 to 2300, Climatic Change, 109, 213-241, https://doi.org/10.1007/s10584-011-0156-z, 2011.

Meul, S., Langematz, U., Oberländer, S., Garny, H., and Jöckel, P.: Chemical contribution to future tropical ozone change in the lower stratosphere, Atmos. Chem. Phys., 14, 2959-2971, https://doi.org/10.5194/acp-14-2959-2014, 2014.

Meul, S., Dameris, M., Langematz, U., Abalichin, J., Kerschbaumer, A., Kubin, A., and Oberländer-Hayn, S.: Impact of rising greenhouse gas concentrations on future tropical ozone and UV exposure, Geophys. Res. Lett., 43, 2919-2927, https://doi.org/10.1002/2016GL067997, 2016.

Monks, P. S., Granier, C., Sandro, F., Stohl, A., Williams, M., Akimoto, H., Amann, M., Baklanov, A., Baltensperger, U., Bey, I., Blake, N., Blake, R., Carslaw, K., Cooper, O. R., Dentener, F., Fowler, D., Fragkou, E., Frost, G., Generoso, S., and von Glasow, R.: Atmospheric composition change - global and regional air quality, Atmos. Environ., 43, 33, 5268-5350, https://doi.org/10.1016/j.atmosenv.2009.08.021, 2009.

Neu, J. L., Flury, T., Manney, G. L., Santee, M. L., Livesey, N. J., and Worden, J.: Tropospheric ozone variations governed by changes in stratospheric circulation, Nat. Geosci, 7, 340-344, https://doi.org/10.1038/ngeo2138, 2014.

Nevison, C. D., Solomon, S., and Gao, R. S.: Buffering interactions in the modeled response of stratospheric $\mathrm{O}_{3}$ to increased $\mathrm{NO}_{x}$ and $\mathrm{HO}_{x}$, J. Geophys. Res., 104, 3741-3754, https://doi.org/10.1029/1998JD100018, 1999.

Oberländer, S., Langematz, U., and Meul, S.: Unraveling impact factors for future changes in the Brewer-Dobson circulation, J. Geophys. Res.-Atmos., 118, 10296-10312, https://doi.org/10.1002/jgrd.50775, 2013.

Olsen, S. C., McLinden, C. A., and Prather, M. J.: Stratospheric $\mathrm{N}_{2} \mathrm{O}-\mathrm{NO}_{y}$ system: Testing uncertainties in a threedimensional framework, J. Geophys. Res., 106, 28771, https://doi.org/10.1029/2001JD000559, 2001.

Ordóñez, C., Brunner, D., Staehelin, J., Hadjinicolaou, P., Pyle, J. A., Jonas, M., Wernli, H., and Prévôt, A. S. H.: Strong influence of lowermost stratospheric ozone on lower tropospheric background ozone changes over Europe, Geophys. Res. Lett., 34, L07805, https://doi.org/10.1029/2006GL029113, 2007.

Pan, L. L., Wei, J. C., Kinnison, D. E., Garcia, R. R., Wuebbles, D. J., and Brasseur, G. P.: A set of diagnostics for evaluating chemistry-climate models in the extratropical tropopause region, J. Geophys. Res., 112, D09316, https://doi.org/10.1029/2006JD007792, 2007.

Revell, L. E., Bodeker, G. E., Huck, P. E., Williamson, B. E., and Rozanov, E.: The sensitivity of stratospheric ozone changes through the 21 st century to $\mathrm{N}_{2} \mathrm{O}$ and $\mathrm{CH}_{4}$, Atmos. Chem. Phys., 12, 11309-11317, https://doi.org/10.5194/acp-12-113092012, 2012.

Roeckner, E., Brokopf, R., Esch, M., Giorgetta, M., Hagemann, S., Kornblueh, L., Manzini, E., Schlese, U., and Schulzweida, U.: Sensitivity of simulated climate to horizontal and vertical resolution in the ECHAM5 atmosphere model, J. Clim., 19, 37713791, 2006.

Roelofs, G.-J. and Lelieveld, J.: Model study of the influence of cross-tropopause $\mathrm{O}_{3}$ transports on tropospheric $\mathrm{O}_{3}$ levels, Tellus B, 49, 38-55, 1997.

Sander, R., Baumgaertner, A., Gromov, S., Harder, H., Jöckel, P., Kerkweg, A., Kubistin, D., Regelin, E., Riede, H., Sandu, A., Taraborrelli, D., Tost, H., and Xie, Z.-Q.: The atmospheric chemistry box model CAABA/MECCA-3.0, Geosci. Model Dev., 4, 373-380, https://doi.org/10.5194/gmd-4-373-2011, 2011.

Sander, S. P., Abbatt, J., Barker, J. R., Burkholder, J. B., Friedl, R. R., Golden, D. M., Huie, R. E., Kolb, C. E., Kurylo, M. J., Moortgat, G. K., Orkin, V. L., and Wine, P. H.: Chemical Kinetics and Photochemical Data for Use in Atmospheric Studies, Evaluation No. 17, JPL Publication 10-6, Jet Propulsion Laboratory, Pasadena, available at: http://jpldataeval.jpl.nasa.gov (last access: 23 March 2016), 2011.

Shindell, D. T., Faluvegi, G., Unger, N., Aguilar, E., Schmidt, G. A., Koch, D. M., Bauer, S. E., and Miller, R. L.: Simulations of preindustrial, present-day, and 2100 conditions in the NASA GISS composition and climate model G-PUCCINI, Atmos. Chem. Phys., 6, 4427-4459, https://doi.org/10.5194/acp-64427-2006, 2006.

Schmidt, H., Rast, S., Bunzel, F., Esch, M., Giorgetta, M., Kinne, S., Krismer, T., Stenchikov, G., Timmreck, C., Tomassini, L., and Walz, M.: Response of the middle atmosphere to anthropogenic and natural forcings in the CMIP5 simulations with the Max Planck Institute Earth system model, J. Adv. Model. Earth Syst., 5, 98-116, https://doi.org/10.1002/jame.20014, 2013.

Škerlak, B., Sprenger, M., and Wernli, H.: A global climatology of stratosphere-troposphere exchange using the ERA-Interim data set from 1979 to 2011, Atmos. Chem. Phys., 14, 913-937, https://doi.org/10.5194/acp-14-913-2014, 2014.

Stevenson, D. S., Dentener, F. J., Schultz, M. G., Ellingsen, K., van Noije, T. P. C., Wild, O., Zeng, G. Amann, M., Ather- 
ton, C. S., Bell, N., Bergmann, D. J., Bey, I., Butler, T., Cofala, J., Collins, W. J., Derwent, R. G., Doherty, R. M., Drevet, J., Eskes, H. J., Fiore, A. M., Gauss, M., Hauglustaine, D. A., Horowitz, L. W., Isaksen, I. S. A., Krol, M. C., Lamarque, J.-F., Lawrence, M. G., Montanaro, V., Müller, J.-F., Pitari, G., Prather, M. J., Pyle, J. A., Rast, S., Rodriguez, J. M., Sanderson, M. G., Savage, N. H., Shindell, D. T., Strahan, S. E., Sudo, K., and Szopa, S.: Multimodel ensemble simulations of present-day and near-future tropospheric ozone, J. Geophys. Res., 111, D08301, https://doi.org/10.1029/2005JD006338, 2006.

Stohl, A., Bonasoni, P., Cristofanelli, P., Collins, W., et al.: Stratosphere-troposphere exchange: A review, and what we have learned from STACCATO, J. Geophys. Res., 108, 8516, https://doi.org/10.1029/2002JD002490, 2003.

Sudo, K., Takahashi, M., and Akimoto, H.: Future changes in stratosphere-troposphere exchange and their impacts on future tropospheric ozone simulations, Geophys. Res. Lett., 30, 2256, https://doi.org/10.1029/2003GL018526, 2003.

Tian, W., Chipperfield, M. P., Stevenson, D. S., Damoah, R., Dhomse, S.,Dudhia, A., Pumphrey, H., and Bernath, P.: Effects of stratosphere-troposphere chemistry coupling on tropospheric ozone, J. Geophys. Res., 115, D00M04, https://doi.org/10.1029/2009JD013515, 2010.

Wild, O.: Modelling the global tropospheric ozone budget: exploring the variability in current models, Atmos. Chem. Phys., 7, 2643-2660, https://doi.org/10.5194/acp-7-2643-2007, 2007.
WMO (World Meteorological Organisation): Scientific Assessment of Ozone Depletion: 2010, Global Ozone Research and Monitoring Project-Report No. 52, 516 pp., World Meteorol. Organ., Geneva, Switzerland, 2011.

WMO (World Meteorological Organisation): Scientific Assessment of Ozone Depletion: 2014, Global Ozone Research and Monitoring Project-Report No. 55, 416 pp., World Meteorol. Organ., Geneva, Switzerland, 2014.

Young, P. J., Archibald, A. T., Bowman, K. W., Lamarque, J.-F., Naik, V., Stevenson, D. S., Tilmes, S., Voulgarakis, A., Wild, O., Bergmann, D., Cameron-Smith, P., Cionni, I., Collins, W. J., Dalsøren, S. B., Doherty, R. M., Eyring, V., Faluvegi, G., Horowitz, L. W., Josse, B., Lee, Y. H., MacKenzie, I. A., Nagashima, T., Plummer, D. A., Righi, M., Rumbold, S. T., Skeie, R. B., Shindell, D. T., Strode, S. A., Sudo, K., Szopa, S., and Zeng, G.: Preindustrial to end 21st century projections of tropospheric ozone from the Atmospheric Chemistry and Climate Model Intercomparison Project (ACCMIP), Atmos. Chem. Phys., 13, 20632090, https://doi.org/10.5194/acp-13-2063-2013, 2013.

Zeng, G. and J. A. Pyle: Changes in tropospheric ozone between 2000 and 2100 modeled in a chemistry-climate model, Geophys. Res. Lett., 30, 1392, https://doi.org/10.1029/2002GL016708, 2003.

Zeng, G., Morgenstern, O., Braesicke, P., and Pyle, J. A.: Impact of stratospheric ozone recovery on tropospheric ozone and its budget, Geophys. Res. Lett., 37, L09805, https://doi.org/10.1029/2010GL042812, 2010. 